\title{
Chiral cooperativity in diastereomeric diphosphite ligands: effects on the rhodium-catalyzed enantioselective hydroformylation of styrene
}

\section{Citation for published version (APA):}

Buisman, G. J. H., Veen, van der, L. A., Klootwijk, A., Lange, de, W. G. J., Kramer, P. C. J., Leeuwen, van, P. W. N. M., \& Vogt, D. (1997). Chiral cooperativity in diastereomeric diphosphite ligands: effects on the rhodiumcatalyzed enantioselective hydroformylation of styrene. Organometallics, 16(13), 2929-2939.

https://doi.org/10.1021/om970172d

DOI:

10.1021/om970172d

Document status and date:

Published: 01/01/1997

\section{Document Version:}

Publisher's PDF, also known as Version of Record (includes final page, issue and volume numbers)

\section{Please check the document version of this publication:}

- A submitted manuscript is the version of the article upon submission and before peer-review. There can be important differences between the submitted version and the official published version of record. People interested in the research are advised to contact the author for the final version of the publication, or visit the DOI to the publisher's website.

- The final author version and the galley proof are versions of the publication after peer review.

- The final published version features the final layout of the paper including the volume, issue and page numbers.

Link to publication

\footnotetext{
General rights

- You may freely distribute the URL identifying the publication in the public portal. follow below link for the End User Agreement:

www.tue.nl/taverne

\section{Take down policy}

If you believe that this document breaches copyright please contact us at:

openaccess@tue.nl

providing details and we will investigate your claim.
}

Copyright and moral rights for the publications made accessible in the public portal are retained by the authors and/or other copyright owners and it is a condition of accessing publications that users recognise and abide by the legal requirements associated with these rights.

- Users may download and print one copy of any publication from the public portal for the purpose of private study or research.

- You may not further distribute the material or use it for any profit-making activity or commercial gain

If the publication is distributed under the terms of Article $25 \mathrm{fa}$ of the Dutch Copyright Act, indicated by the "Taverne" license above, please 


\title{
Chiral Cooperativity in Diastereomeric Diphosphite Ligands: Effects on the Rhodium-Catalyzed Enantioselective Hydroformylation of Styrene
}

\author{
Godfried J . H. Buisman, ${ }^{\dagger}$ Lars A. van der Veen, ${ }^{\dagger}$ Angélique Klootwijk, ${ }^{\dagger}$ \\ Wim G. J . de Lange, ${ }^{\dagger}$ Paul C. J . Kamer, ${ }^{*},{ }^{\dagger}$ Piet W. N. M. van Leeuwen, ${ }^{\dagger}$ and \\ Dieter Vogt $^{\ddagger}$ \\ J . H. van het H off Research Institute, Department of Inorganic Chemistry, \\ Homogeneous Catalysis, University of Amsterdam, Nieuwe Achtergracht 166, \\ 1018 WV Amsterdam, The Netherlands, and Institut für Technische Chemie und \\ Petrol chemie der Rheinisch-Westfälischen Technischen Hochschule Aachen, \\ Templergraben 55, 52056, Aachen, Germany
}

Received March 3, $1997^{\otimes}$

\begin{abstract}
Diastereomeric diphosphites $(\mathrm{L} \cap \mathrm{L}=\mathbf{3}-\mathbf{8})$ have been synthesized from enantiomerically pure pentane-2,4-diol and axially chiral 3,3'-bis(trialkylsilyl)-2,2'-bisphenol phosphorochloridites and 3,3'-bis(trialkylsilyl)-2,2'-bisnaphthol phosphorochloridites. These diphosphites have been used to test the influence of chiral cooperativity in the rhodium-catalyzed asymmetric hydroformylation of styrene. Systematic variation in chirality at both the chiral ligand bridge and the axially chiral biphenyl and binaphthyl substituents revealed a remarkable effect on the sel ectivity of the hydroformylation catalysts. For the atropisomeric bisnaphthol-based diphosphites, cooperative effects were observed in the asymmetric hydroformylation of styrene. High enantioselectivities (87\%) and regioselectivities up to $95 \%$ for 2-phenylpropanal were found under mild reaction conditions (15-50 ${ }^{\circ} \mathrm{C}, 20$ bar of syn gas $\mathrm{CO}-\mathrm{H}_{2}$ [1:1]) for the ligand derived from (2R,4R)-pentane-2,4-diol and (S)bisnaphthol. The same high enantiomeric excess was observed for the freerotating bisphenol-substituted ligands. The highest selectivity was obtained with trimethylsilyl substituents at the ortho position. The solution structures of the active catalysts [HRhL $\cap \mathrm{L}$ $(\mathrm{CO})_{2}$ complexes $(\mathrm{L} \cap \mathrm{L}=\mathbf{3}-\mathbf{8})$ ], have been studied by ${ }^{31} \mathrm{P}$ and ${ }^{1} \mathrm{H} N \mathrm{NR}$ spectroscopy at variable temperature (313-213 K). Spectroscopic data, in combination with the obtained results in catalysis, suggest that diphosphite ligands $(L \cap L)$ containing the conformationally flexible axially chiral biphenyl moi eties predominantly exist as single atropisomers in the HRhL $\cap \mathrm{L}$ $(\mathrm{CO})_{2}$ complexes. Comparison of the bisphenol and bisnaphthol substituents suggests that the high enantiomeric excesses obtained with the former are caused by the preferential formation of the most selective diastereomer.
\end{abstract}

\section{Introduction}

In the last 3 decades a considerable amount of research has been devoted to phosphine ${ }^{1-}$ and phosphite ${ }^{2}$-modified homogeneous hydroformylation catalysts. While phosphine-modified platinum hydroformylation catalysts require rather severe reaction conditions and generally are not very chemo- and regioselective,

\footnotetext{
† University of Amsterdam.

¥ Technischen Hochschule Aachen.

${ }^{\otimes}$ Abstract published in Advance ACS Abstracts, May 15, 1997.

(1) For phosphine-modified platinum hydroformylation catalysts, see: (a) Consiglio, G.; Pino, P. Top. Curr. Chem. 1982, 105, 77. (b) Stille, J. K.; Su, H.; Brechot, P.; Parinello, P.; Hegedus, L. S. Organometallics 1991, 10, 1183. (c) Consiglio, G.; Nefkens, S. C. A.; Borer, A. Organometallics 1991, 10, 2046.

(2) For phosphite-modified rhodium hydroformylation catalysts, see: (a) van Leeuwen, P. W. N. M.; Roobeek, C. F. J . Organomet. Chem. 1983, 258, 343. (b) Billig, E.; Abatjoglou, A. G.; Bryant, D. R. Eur. Patent 861 122-562, to Union Carbide, 1986. (c) Bahrman, H.; Fell, B.; Papadogianakis, G. DE 3942954 A1, to Hoechst, 1991. (d) Trzeciak, A. M.: Ziólkowski, J. J. J . Organomet. Chem. 1994, 464, 107 and references cited therein. (e) Polo, A.; Claver, C.; Castillón, S.; Bayón, J. C. J . Chem. Soc., Chem. Commun. 1990, 600. (f) J ongsma, T.; Fossen, M.; Challa, G.; van Leeuwen, P. W. N. M. J . Mol. Catal. 1993, 83, 17. (g) van Rooy, A.; Orij, E. N.; Kamer, P. C. J .; van den Aardweg, F.; van Leeuwen, P. W. N. M. J . Chem. Soc., Chem. Commun. 1991, 1096. (h) Cuny, G. D.; Buchwald, S. L. J . Am. Chem. Soc. 1993, 115, 2066. (i) Billig, E.; Abatjoglou, A. G.; Bryant, D. R. U.S. Patents 4,668,651, 1987, and 4,769,498, 1988.
}

phosphite-modified rhodium catalysts operate under mild reaction conditions, producing a high proportion of aldehydes. As a result, the application of chiral phosphites in hydroformylation catalysts has been recently exploited as an efficient route to enantiomerically pure aldehydes. ${ }^{3}$ The products can be used as precursors for the synthesis of high-value-added compounds such as pharmaceuticals, agrochemicals, flavors, and fragrances. ${ }^{4}$ Wink and co-workers were the first to report on the rhodium-catalyzed hydroformylation of styrene with chiral diphosphites as ligands. Achiral propanediol bridges, substituted with chiral (bis)dioxaphospholanes as chiral auxiliaries, were used, but the reaction lacked enantioselectivity. ${ }^{5}$ In contrast, Takaya et al. reported on the asymmetric hydroformylation of vinyl acetate with enantiosel ectivities up to $49 \%$ with chiral bis(triarylphosphite)-rhodium(I) complexes. ${ }^{6}$

(3) For recent advances in enantioselective hydroformylation, see: Gladiali, S.; Bayón, J. C.; Claver, C. Tetrahedron: Asymmetry 1995, 6,1453 and references cited therein.

(4) (a) Rieu, J.-P.; Bouchelere, A.; Cousse, H.; Mouzin, G. Tetrahe dron 1986, 42, 4095. (b) Botteghi, C.; Paganelli, S.; Schionato, A.; Marchetti, M. Chirality 1991, 3, 355. (c) Botteghi, C.; Del Ponte, G.; Marchetti, M.; Paganelli, S. J. Mol. Catal. 1994, 93, 1.

(5) (a) Wink, D. J .; Kwok, T.J .; Yee, Y., Inorg. Chem. 1990, 29, 5006 (b) Kwok, T. J .; Wink, D. J . Organometallics 1993, 12, 1954. 


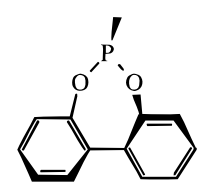

$S$

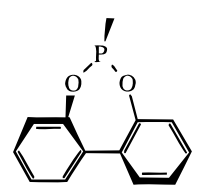

$R$
Figure 1. Atropisomerism in dibenzo[d,f][1,3,2]dioxaphosphepins.

Recent contributions have shown that diphosphites containing both a chiral ligand bridge and additional axially chiral biphenyl or binaphthyl substituents are efficient ligands in the rhodium-catalyzed asymmetric hydroformylation of various olefinic substrates. ${ }^{6-11}$ An important breakthrough was reported by Union Carbide. They used bulky diphosphites derived from homochiral 2,4-pentanediol and obtained high enantioselectivities in the asymmetric hydroformylation of styrene of around $90 \%{ }^{8}$ From NMR and I R spectroscopy it was concluded that particularly diphosphites containing a chiral 1,3-diol ligand bridge form stable and enantioselective rhodium hydroformylation catalysts. ${ }^{7,10,11}$ Since the biaryl moieties of the diphosphites used in this study contain bulky substituents, hindered rotation around the biaryl axis can be expected. The additional chirality originating from the atropisomeric biaryl substituents results in several possible diastereomers. Since low rotational barriers have been reported in compounds containing dibenzo[d,f][1,3,2]dioxaphosphepins (F igure $1)^{12,13}$ it is reasonable to assume that the actual rhodium diphosphite catalyst can consist of several diastereomers. Complex formation from chiral ligands and chiral substrates can give matched and mismatched diastereomers, resulting in double stereodifferentiation. ${ }^{14}$ A study of Burgess et al. on asymmetric hydrogenation with DIOP-DIPAMP hybrid ligands showed moderate differences between matched and mismatched diastereomeric ligands. ${ }^{15}$ Chiral cooperativity between two modes of chirality was reported by Togni and Pastor for the gold-catalyzed aldol reaction using chiral ferrocenylamine ligands. ${ }^{16}$

(6) Sakai, N.; Nozaki, K.; Mashinma, K.; Takaya, H. Tetrahedron: Asymmetry 1992, 3, 583.

(7) Buisman, G. J. H.; Kamer, P. C. J .; van Leeuwen, P. W. N. M. Tetrahedron: Asymmetry 1993, 4, 1625.

(8) Babin, J . E.; Whiteker, G. T. WO 93/03839, US 911,518, 1992. (9) (a)Higashizima, T., Sakai, N.; Nozaki, K.; Takaya, H. Tetrahe dron Lett. 1994, 35, 2023. (b)Sakai, N.; Mano, S.; Nozaki, K.; Takaya, H. J . Am. Chem. Soc. 1993, 115, 7033. (c) Sakai, N.; Nozaki, K.; Takaya, H. J . Chem. Soc., Chem. Commun. 1994, 395.

(10) (a) van Leeuwen, P. W. N. M.; Buisman, G. J . H.; van Rooy, A.; Kamer, P. C. J . Red. Trav. Chim. Pays-Bas 1994, 113, 61. (b) Buisman, G. J . H.; Vos, E. J .; Kamer, P. C. J .; van Leeuwen, P. W. N. M. J. Chem. Soc., Dalton Trans. 1995, 409. (c) van Rooy, A.; Kamer, P. C. J .; van Leeuwen, P. W. N. M.; Veldman, N.; Spek, A. L. J . Organomet. Chem. 1995, 494, C15-C18.

(11) Buisman, G. J . H.; Martin, M. E.; Vos, E. J .; Klootwijk, A.; Kamer, P. C. J .; van Leeuwen, P. W. N. M. Tetrahedron: Asymmetry 1995, 6, 719.

(12) (a) Whiteker, G. T.; Harrison, A. M.; Abatjoglou, A. G.J . Chem. Soc., Chem. Commun. 1995, 1805. (b) Hans, J .; Day, R. O.; Howe, L.; Holmes, R. R. Inorg. Chem. 1992, 31, 1279. (c) Prakasha, T. K.; Day, R. O.; Holmes, R. R. Inorg. Chem. 1992, 31, 1913. (d) Kumara Swamy, K. C.; Day, R. O.; Holmes, R. R. J . Am. Chem. Soc. 1990, 112, 6095. (e) Baker, M. J .; Harrison, K. N.; Orpen, A. G.; Pringle, P. G.; Shaw, G. J. Chem. Soc., Chem. Commun. 1991, 803.

(13) (a) Pastor, S. D.; Rodebaugh, R. K.; Odorisio, P. A., Pugin, B.; Rihs, G.; Togni, A. Helv. Chim. Acta 1991, 74, 1175. (b) Pastor, S. D.; Shum, S. P.; Rodebaugh, R. K.; Debellis, A. D.; Clarke, F. H. Helv. Chim. Acta 1993, 76, 900.

(14) Masamune, S.; Choy, W.; Petersen, J . S.; Sita, L. R. Angew. Chem., Int. Ed. Engl. 1985, 24, 1.

(15) Burgess, K.; Ohlmeyer, M.J .; Whitmire, K. H. Organometallics 1992, 11, 3588.
We now report on the asymmetric hydroformylation of styrene using enantiopure ortho-substituted bisnaphthol containing diphosphites. All combinations of the atropisomerically pure binaphthyl moieties and enantiomerically pure bridge could be synthesized. This enabled us to study the origin of the high enantioselectivities obtained with chiral diphosphite ligands. $8,10 \mathrm{~b}$

\section{Results}

Synthesis of Diastereomeric Diphosphite Ligands. To study the effect of chiral cooperativity, we synthesized a series of diphosphites based on homochiral pentane-2,4-diol ligand backbones substituted with bulky 2,2'-bisphenols and bulky 2,2'-bisnaphthols. Since interconversion around the binaphthyl bond is energetically highly unfavorable, stable diastereomeric diphosphites could be obtained in an optically pure form. The absolute configuration of the synthesized diastereomers is given in a shorthand notation as $(S, 2 R, 4 R, S)$, $(S, 2 S, 4 S, S),(R, 2 R, 4 R, R)$, and $(S, 2 R, 4 R, R)$. The indicators $S$ and $R$ refer to the absolute configurations around the chiral axis, while the indicators $2 \mathrm{R}, 4 \mathrm{R}$ and $2 \mathrm{~S}, 4 \mathrm{~S}$ refer to the absolute configurations of carbon atoms $C_{2}$ and $\mathrm{C}_{4}$ in the pentane-2,4-diol backbone. The structures having the configuration $(S, 2 R, 4 R, R)$ and $(R, 2 R, 4 R, S)$ are equivalent as a consequence of the $C_{2}$ symmetry.

Recently the presence of bulky substituents on aromatic biphenyl and binaphthyl positions was shown to have a significant effect on the catalyst performance. $7,8,10,11$ In this study ligands were used with ortho substituents having increasing steric bulk (trimethyl-, triethyl-, and tert-butyldimethylsilyl).

Preparation of 3,3'-Bis(trialkylsilyl)- and 3,3'Bis(triaryl)silyl-Substituted 2,2-Bisphenols and 2,2-Bisnaphthols. For the introduction of ortho trialkyl and triaryl substituents at aromatic positions, we first applied the route recently described by Yamamoto et al. for the synthesis of ortho-substituted 2,2'bisnaphthols. ${ }^{17 a b}$
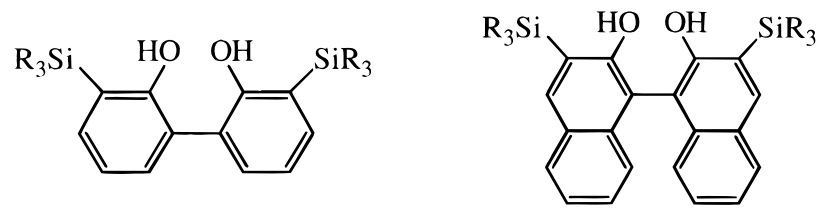

$$
\begin{array}{ll}
\text { 1a } & (\mathrm{R}=\mathrm{Me}) \\
\mathbf{1 b} & (\mathrm{R}=\mathrm{Et}) \\
\mathbf{1 c} & \left(\mathrm{R}_{3}=\text { tert }-\mathrm{BuMe}_{2}\right) \\
\text { 1d } & (\mathrm{R}=\mathrm{Ph})
\end{array}
$$

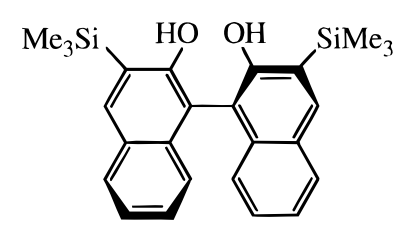

(S) - $\mathbf{2 a}$

\begin{abstract}
$(R / S)-2 \mathrm{a} \quad(\mathrm{R}=\mathrm{Me})$
$(R / S)-2 \mathbf{b} \quad(\mathrm{R}=\mathrm{Et})$

$(R / S)-2 \mathrm{c} \quad\left(\mathrm{R}_{3}=\right.$ tert $\left.-\mathrm{BuMe}_{2}\right)$

$(R / S)-2 d \quad(\mathrm{R}=\mathrm{Ph})$
\end{abstract}

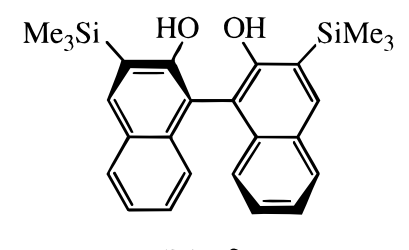

(R) - $\mathbf{2 a}$
(16) Togni, A.; Pastor, S. D. J . Org. Chem. 1990, 55, 1649.

(17) (a) Maruoka, K.; Itoh, T.; Araki, Y.; Shirasaka, T., Yamamoto, H. Bull. Chem. Soc. J pn. 1988, 61, 2975. (b) Maruoka, K.; I toh, T. Shirasaka, T.; Yamamoto, H. J. Am. Chem. Soc. 1988, 110, 310. (c) Billedeau, R. J.; Sibi, M. P.; Snieckus, V. Tetrahedron Lett. 1983, 24, 4515. (d) Heinicke, J .; Nietzschmann, E.; Tzschach, A. J . Organometal. Chem. 1983, 243, 1. (e) Arai, I.; Park, K. H.; Daves, G. D. J . Organometal. Chem. 1976, 121, 25. 
Scheme 1. Straightforward Reaction Route to 3,3'-Bis(trimethylsilyl)-2,2'-bisphenol (1a)
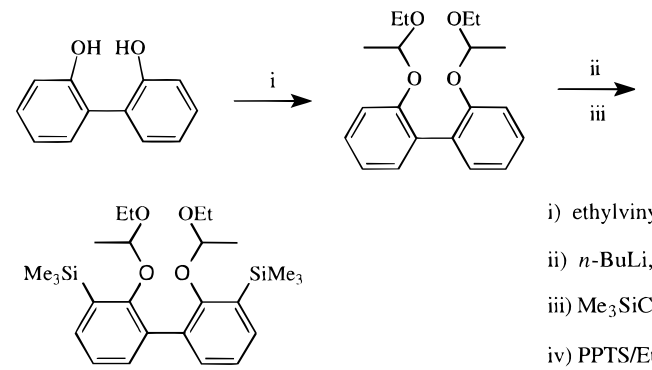

i) ethylvinyl ether (EVE), PPTS

ii) $n$-BuLi, r.t.

iii) $\mathrm{Me}_{3} \mathrm{SiCl},-78^{\circ} \mathrm{C}$

iv) PPTS/EtOH, $50{ }^{\circ} \mathrm{C}$

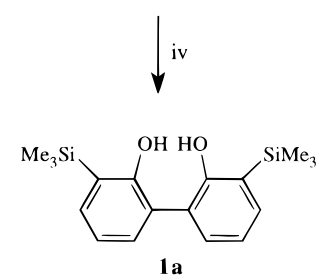

The ortho lithiation of 2,2'-dimethoxy-1,1'-biphenyl followed by reaction with bromine was accompanied by the formation of about $25 \%$ of a regioisomer of 3,3'dibromo-2,2'-dimethoxy 1,1'-biphenyl. In contrast with results reported by Yamamoto, ${ }^{17}$ the final products, 2,2'bis(trimethylsilyl) ethers of 2,2'-bisphenol and 2,2'bisnaphthol, were not stable during short path column purification on silica gel. The overall yield was very low and therefore a more straightforward reaction route was applied for the preparation of o-bis(trimethylsilyl)substituted diaryl dialcohols $\mathbf{1}$ and $\mathbf{2}$. Ethyl vinyl ether (EVE) was used in combination with pyridinium ptoluenesulfonate (PPTS) for protection of the hydroxy groups in quantitative yields (Scheme 1, step i). ${ }^{18,19}$

A one-pot synthesis comprising bis ortho lithiation followed by reaction with trimethylsilyl chloride (Scheme 1 , $\mathrm{ii}$ and $\mathrm{iii}$ ) resulted in the formation of 3,3'-bis(trimethyl silyl)-2,2'-bis(1-ethoxyethoxy)-1,1'-biphenyl. Deprotection with pyridinium p-toluenesulfonate ${ }^{19}$ in ethanol under mild reaction conditions (Scheme 1, iv) gave $\mathbf{1 a}$ in only four reaction steps (overall yield $32 \%$ ). The same procedures were applied to obtain racemic (R/ S)-( $( \pm)-\mathbf{2 a}$ and enantiomerically pure (S)-(-)-2a and (R)(+)-2a in an overall yield up to $85 \%$. $\beta$-Methoxyethoxymethyl ethers ${ }^{20}$ (MEM) have also been used as protecting groups, but this resulted in low selectivity in the lithiation step. ${ }^{21}$

Preparation of Diastereomeric Diphosphites ( $\mathbf{L} \cap \mathbf{L}=\mathbf{3}-\mathbf{8})$. Optically pure $(2 R, 4 R)$ - and $(2 S, 4 S)$ pentane-2,4-diol have been used as $C_{2}$ symmetrical backbones for the synthesis of the diphosphites 3-8. The bis o-trialkylsilyl-substituted diols $\mathbf{1}$ and $\mathbf{2}$ reacted quantitatively with 1 equiv of phosphorus trichloride to yield the corresponding phosphorochloridites in the presence of a base. Diphosphites $\mathbf{3 a}-\mathbf{c}, \mathbf{4 a}-\mathbf{c}$, and 5-7 were synthesized in good yields (47-96\% isolated) by adding 2 equiv of the phosphorochloridite to enantiomerically pure pentane-2,4-diol in the presence of triethylamine. Via the same route, the preparation of the

(18) Narasimhan, N. S.; Mali, R. S. Top. Curr. Chem. 1987, 138, 116.

(19) Miyashita, M.; Yoshikoshi, A.; Grieco, P. A. J . Org. Chem. 1977, $42,3772$.

(20) (a) Corey, E. J .; Gras, J .-L.; Ulrich, P. Tetrahedron Lett. 1976, 11, 809. (b) Narasimhan, N. S.; Mali, R. S.; Barve, M. V. Synthesis 1979, 906.

(21) Mayrargue, J .; Essamkaoui, M.; Moskowitz, H. Tetrahedron Lett. 1989, 30, 6867. bulky diphosphite $\mathbf{3 d}$ and $\mathbf{4 d}(\mathrm{R}=\mathrm{Ph})$ resulted in the formation of mono-substituted diol accompanied by a considerable amount of hydrolyzed phosphorochloridite. Attempts to synthesize $\mathbf{3 d}$ by adding 2 equiv of phosphorochloridite to the more reactive $(2 R, 4 R)$-pentane2,4-diol ate were not successful either. ${ }^{22}$ Diphosphite 8 , having the configuration $(R, 2 R, 4 R, S)$, was synthesized via a two-step procedure. One equivalent of the phosphorochloridite derived from (R)-(+)-2a was added to $(2 \mathrm{R}, 4 \mathrm{R})$-pentane-2,4-diol. The mono-substituted product was isolated from the reaction mixture and transformed to $\mathbf{8}$ in a subsequent reaction with the phosphorochloridite derived from (S)-(-)-2a.

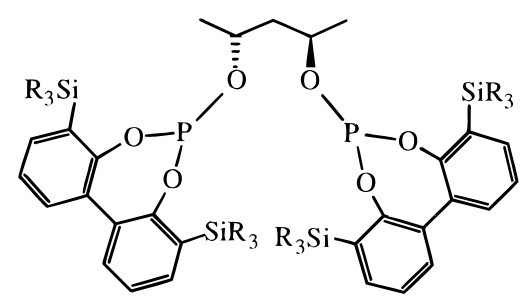

$$
\begin{array}{ll}
\text { 3a } & (\mathrm{R}=\mathrm{Me}) \\
\mathbf{3 b} & (\mathrm{R}=\mathrm{Et}) \\
\mathbf{3 c} & \left(\mathrm{R}_{3}=\text { tert }-\mathrm{BuMe}_{2}\right) \\
\mathbf{3 d} & (\mathrm{R}=\mathrm{Ph})
\end{array}
$$

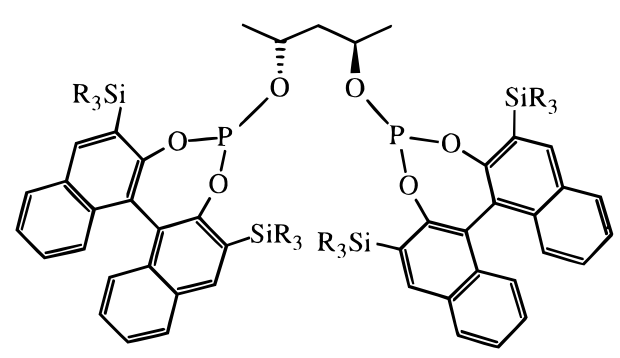

$$
\begin{array}{ll}
\mathbf{4 a} & (\mathrm{R}=\mathrm{Me}) \\
\mathbf{4 b} & (\mathrm{R}=\mathrm{Et}) \\
\mathbf{4 c} & \left(\mathrm{R}_{3}=\text { tert }-\mathrm{BuMe}_{2}\right) \\
\mathbf{4 d} & (\mathrm{R}=\mathrm{Ph})
\end{array}
$$

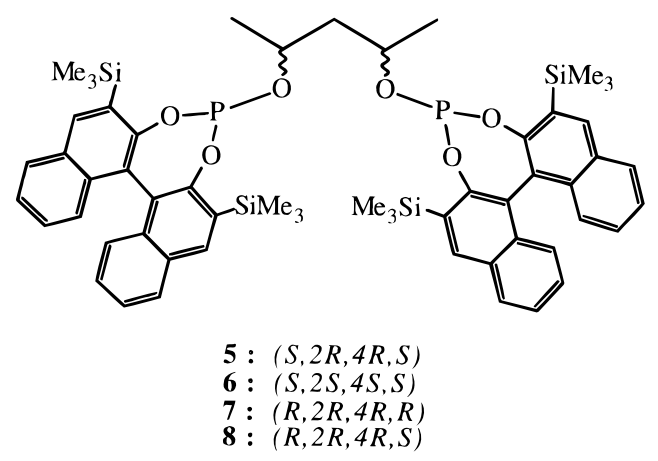

Diphosphites 3-8 were purified by column chromatography on silica gel and characterized by ${ }^{31} \mathrm{P},{ }^{13} \mathrm{C}$, and ${ }^{1} \mathrm{H}$ NMR spectroscopy. At room temperature, no diastereomers could be observed for $\mathbf{3}$ with NMR, which suggests that a fast interconversion around the biphenyl bonds results in a time-averaged configuration on the NMR time scale. These observations are consistent with results recently reported in a variable temperature

(22) For the synthesis of other steric congested diphosphites via reactive diolates, see: (a) Pastor, S. D.; Spivack, J . D.; Steinhuebel. L P. Phosphorus Sulfur 1985, 22, 169. (b) Pastor, S. D.; Hyun, J. L.; Odirisio, P. A.; Rodebaugh, R. K. J . Am. Chem. Soc. 1988, 110, 6547. 


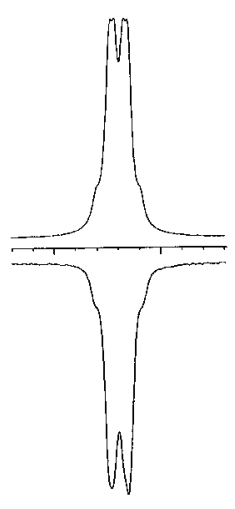

A

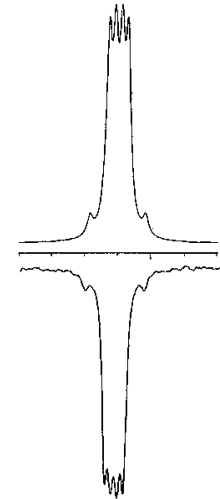

B
Figure 2. (A) Calculated and recorded (lower trace) ${ }^{31} \mathrm{P}-$ ${ }^{1} \mathrm{H}$ NMR spectrum of $3 \mathbf{a}\left(\delta=145.1 \mathrm{ppm},{ }^{3}\right)$ PHbackbone $=5.5$ $\mathrm{Hz},{ }^{6} \mathrm{pp}=5.2 \mathrm{~Hz}$ ). (B) Calculated and recorded (lower trace) ${ }^{31} \mathrm{P}-{ }^{1} \mathrm{H}$ NMR spectrum of $\mathbf{3 b}(\delta=147.1 \mathrm{ppm}$, 3) PHbackbone $=7.0 \mathrm{~Hz}, 6 \mathrm{pP}=9.0 \mathrm{~Hz}$ ).

NMR study by Whiteker et al. ${ }^{12 a}$ High-resolution (0.1 $\mathrm{Hz}$ ) proton-coupled phosphorus NMR showed secondorder multiplets for $\mathbf{3 a}$ and $\mathbf{3 b}$ (Figure 2, parts $a$ and b, respectively). The calculated spin-simulated ${ }^{31} \mathrm{P}-{ }^{1} \mathrm{H}$ NMR spectra revealed phosphorus-phosphorus coupling constants ( $(\mathrm{J}$ pP) of 5.2 and $9.0 \mathrm{~Hz}$ for $\mathbf{3 a}$ and $\mathbf{3 b}$, respectively. It is noted that the observed coupling constants may be due to average values of the fast interchanging diastereomers. A recent study by Pastor and co-workers showed different phosphorus-phosphorus coupling constants for diastereomers in the slow exchange limit. ${ }^{13}$ Six-bond phosphorus-phosphorus coupling constants ( 6 pP) in the range of 4.5 and $12 \mathrm{~Hz}$ have been reported by Szalontai ${ }^{23}$ et al. in similar diphosphites. Generally, long-range phosphorus-phosphorus coupling is explained by through space interaction. ${ }^{24}$ Further evidence for through space phosphorusphosphorus coupling was obtained from the ${ }^{13} \mathrm{C}$ NMR spectra. Virtual triplets were found for the aromatic carbon atoms $\mathrm{C}_{1,1^{\prime}}$ and $\mathrm{C}_{3,3^{\prime}}$ of $\mathbf{3} \mathbf{a}$ and $\mathbf{3} \mathbf{b}$ with an observed J PC coupling constant up to $6.8 \mathrm{~Hz}$ (benzene$d_{6}, 293 \mathrm{~K}$ ). The observed coupling constant is an average of the ${ }^{3} \mathrm{p}^{1} \mathrm{C}$ of about $14 \mathrm{~Hz}$ and the ${ }^{9} \mathrm{~J} \mathrm{p}^{2} \mathrm{C}$ of 0 $\mathrm{Hz}$. Diphosphite $\mathbf{3 c}$ did not show any phosphorusphosphorus coupling in either ${ }^{31} \mathrm{P}$ or ${ }^{13} \mathrm{C}$ NMR spectra. We therefore conclude that in $\mathbf{3 c}$ the phosphorus atoms have no interaction with one another in solution. ${ }^{23}$

For $\mathbf{4 a}-\mathbf{c}$ the diastereomers with absolute configurations $(S, 2 R, 4 R, S),(S, 2 R, 4 R, R)$, and $(R, 2 R, 4 R, R)$ were formed in the statistical 1:2:1 molecular ratio, as was concluded from ${ }^{31 P} N M R$. The $(S, 2 R, 4 R, R)$ diastereomer with two inequivalent phosphorus atoms shows ${ }^{31} \mathrm{P}$ NMR signals at different chemical shifts. In contrast, $C_{2}$ symmetrical diastereomers having the configuration $(S, 2 R, 4 R, S)$ and $(R, 2 R, 4 R, R)$ give rise to single ${ }^{31} \mathrm{P}$ absorptions. The four expected signals were observed with equal intensities. Diastereomeric mixtures of $\mathbf{4 a - c}$ were purified from residual side products by column chromatography on silica gel. No detailed characterization by ${ }^{13} \mathrm{C}$ and ${ }^{1} \mathrm{H}$ NMR has been carried

(23) (a) Szalontai, G.; Bakos, J .; Tóth, I.; Pelczer, I.; Soharár, P. Phosphorus Sulfur 1987, 30, 734. (b) Szalontai, G.; Bakos, J .; Tóth, I.; Heil, B. Magn. Reson. Chem. 1987, 75, 761.

(24) (a) Hilton, J .; Sutcliffe, L. H. Prog. NMR Spectrosc. 1975, 10, 27. (b) Mallory, F. B.; Mallory, C. W.; Baker, M. B. J . Am. Chem. Soc. 1990, 112, 2577.
Table 1. ${ }^{31} \mathrm{P}$ and ${ }^{1} \mathrm{H}$ NMR Data of $\mathrm{HRhL} \cap \mathrm{L}(\mathrm{CO})_{2}$ Complexes, $\mathbf{L} \cap \mathbf{L}=3-8^{\mathrm{a}, \mathrm{b}}$

\begin{tabular}{|c|c|c|c|c|c|c|}
\hline \multirow[b]{2}{*}{$\mathrm{L} \cap \mathrm{L}$} & \multirow[b]{2}{*}{$\mathrm{T}(\mathrm{K})$} & \multicolumn{2}{|l|}{$\delta$} & \multirow[b]{2}{*}{$1^{1} R h-P^{d}$} & \multirow[b]{2}{*}{${ }^{1} \mathrm{Jh}_{\mathrm{R}-\mathrm{H}^{\mathrm{d}}}$} & \multirow[b]{2}{*}{${ }^{2} \mathrm{P}_{\mathrm{P}} \mathrm{H}^{\mathrm{d}}$} \\
\hline & & ${ }^{31} \mathrm{pc}^{\mathrm{c}}$ & ${ }^{1} \mathrm{H}^{\mathrm{c}}$ & & & \\
\hline $3 a$ & 333 & 163.5 & -10.57 & 232.1 & 5.0 & 3.0 \\
\hline 3b & 293 & 162.4 & -10.48 & 227.2 & 6.0 & 9.0 \\
\hline 3c & 293 & 166.0 & -10.37 & 236.9 & 3.0 & $<2.0$ \\
\hline 5 & 293 & 166.3 & -10.28 & 232.1 & 3.0 & $<2.0$ \\
\hline 6 & 293 & $158.4^{e}$ & -10.44 & $232.1^{e}$ & $<2.0$ & $<2.0$ \\
\hline 7 & 293 & $e, f$ & -10.42 & $e, f$ & $<2.0$ & $<2.0$ \\
\hline 8 & 293 & $167.6,166.5$ & -10.24 & $\begin{array}{r}235.1 \\
234.2\end{array}$ & $<2.0$ & $<2.0$ \\
\hline
\end{tabular}

a Prepared in toluene- $\mathrm{d}_{8} .{ }^{31} \mathrm{P}\left\{{ }^{1} \mathrm{H}\right\},{ }^{31} \mathrm{P}$, and ${ }^{1} \mathrm{H}$ spectra recorded under atmospheric conditions at room temperature. ${ }^{c}$ Chemical shifts $(\delta)$ in ppm. ${ }^{d}$ Coupling constants $(J)$ in hertz. ${ }^{e}$ Other undefined rhodium species are present. ${ }^{f}$ The ${ }^{31} \mathrm{P}$ NMR chemical shifts could not be determined.

out since the mixtures of diastereomers gave partially overlapping spectra.

The ${ }^{31} \mathrm{P}$ and ${ }^{13} \mathrm{C}$ NMR spectra of $\mathbf{5}$, synthesized from $(2 \mathrm{R}, 4 \mathrm{R})$-pentane-2,4-diol and enantiomerically pure (S)$(-)-2 a,{ }^{25}$ display long-range phosphorus-phosphorus coupling. A phosphorus-phosphorus coupling constant ( $\mathrm{G} \mathrm{pP}$ ) of $13 \mathrm{~Hz}$ was derived from the simulated ${ }^{31} \mathrm{P} \mathrm{NMR}$ spectrum. Virtual triplets were observed for the aromatic carbon atoms $C_{1,1^{\prime}}$ and $C_{3,3^{\prime}}$ with average $J P C$ coupling constants between 3 and $6 \mathrm{~Hz}$. In contrast with the ${ }^{31 P}$ and ${ }^{13} \mathrm{C}$ NMR spectra of 5, no long-range phosphorus-phosphorus interactions could be observed for diphosphites 6-8. The inversed absolute configurations at carbon atoms $\mathrm{C}_{2}$ and $\mathrm{C}_{4}$ of the pentane-2,4-diol backbone and the axial chirality, as well, probably gave rise to solution structures without appreciable timeaveraged phosphorus-phosphorus interaction..$^{23}$

Solution Structures of Hydroformylation CataIysts. Hydridorhodium diphosphite dicarbonyl complexes [HRhL $\cap \mathrm{L}(\mathrm{CO})_{2}, \mathrm{~L} \cap \mathrm{L}=\mathbf{3 a}-\mathbf{c}$ and 5-8] have been prepared and analyzed in situ under standard hydroformylation reaction conditions (Table 1). ${ }^{10,11}$ At 293 $K$ the ${ }^{31} \mathrm{P} N M R$ spectra for $\mathrm{HRhL} \cap \mathrm{L}(\mathrm{CO})_{2}$ complexes $(\mathrm{L} \cap \mathrm{L}=\mathbf{3 a}-\mathbf{c})$ showed broadened doublets (spectral bandwidths: $\Delta \varpi_{1 / 2}$ between 100 and $200 \mathrm{~Hz}$ ), which suggest fluxional processes on the NMR time scale. Further proof for fluxional processes was provided by ${ }^{31} \mathrm{P}$ NMR measurements at variable temperature. At $333 \mathrm{~K}$, the ${ }^{31} \mathrm{P}$ resonance for the compl ex $\mathrm{HRh}(3 \mathrm{a})(\mathrm{CO})_{2}$ appeared as a sharp doublet $\left(\Delta \varpi_{1 / 2}=11 \mathrm{~Hz}\right)$. The ${ }^{31} \mathrm{P}$ NMR signals of $\mathrm{HRh}(5)(\mathrm{CO})_{2}$ (absolute configuration $\mathrm{S}, 2 \mathrm{R}, 4 \mathrm{R}, \mathrm{S})$, appeared al ready as a sharp doublet ( $1 \mathrm{~J} \mathrm{RhP}$ $=232.1 \mathrm{~Hz}, \Delta \varpi_{1 / 2}<20 \mathrm{~Hz}$ ) at room temperature. The enantiomers 6 and 7, with absolute configurations $(S, 2 S, 4 S, S)$ and $(R, 2 R, 4 R, R)$, respectively, showed a rather different behavior upon coordination to rhodium. Attempts to make $\mathrm{HRhL} \cap \mathrm{L}(\mathrm{CO})_{2}$ complexes for these ligands resulted in the formation of a complex mixture of rhodium-diphosphite species. $\mathrm{HRhL} \cap \mathrm{L}(\mathrm{CO})_{3} \mathrm{com}$ plexes in which the diphosphites act as monodentates are probably formed as side products (31P NMR; eg. L $\mathrm{LL}$ $=6, \delta 157.4 \mathrm{ppm}(\mathrm{d})^{1} \mathrm{~J} \mathrm{RhP}=236.9 \mathrm{~Hz}, 142.4 \mathrm{ppm}(\mathrm{s})$ ). Furthermore, the occurrence of considerable ligand decomposition in complexes with $\mathbf{6}$ and $\mathbf{7}$ was evidenced by resonances between 0 and 15 ppm in the ${ }^{31} \mathrm{P}$ NMR

(25) For the synthesis of other enantiomerically pure bisnaphthols, see: (a) Smrcina, M.; Polákova, J .; Vyskocil, S.; Kocovsky, P. J . Org. Chem. 1993, 58, 4534. (b) Brunel, J .-M.; Buono, G. J . Org. Chem. 1993, 58, 7313. (c) Bao, J .; Wulff, W. D. J . Am. Chem. Soc. 1993, 115, 3814 and references cited therein. 
Table 2. NMR Data of $H R h L \cap L(C O)_{2}$ Complexes, $L \cap L=3-8$ at $213 K^{a, b}$

\begin{tabular}{|c|c|c|c|c|c|c|c|c|c|}
\hline \multirow[b]{2}{*}{$\mathrm{L} \cap \mathrm{L}$} & \multicolumn{3}{|c|}{$\delta$} & \multirow[b]{2}{*}{${ }^{1} \mathrm{RhP1}^{\mathrm{d}}$} & \multirow[b]{2}{*}{${ }^{1} \mathrm{RhP2}^{\mathrm{d}}$} & \multirow[b]{2}{*}{${ }^{2} \int_{P 1 P 2}{ }^{d}$} & \multirow[b]{2}{*}{${ }^{1} \mathrm{RhH}^{\mathrm{d}}$} & \multirow[b]{2}{*}{${ }^{2} \mathrm{~J}_{\mathrm{P} 1 \mathrm{H}^{\mathrm{d}}}$} & \multirow[b]{2}{*}{ 2] $P 2 H^{d}$} \\
\hline & ${ }^{31} P_{1} c$ & ${ }^{31} P_{2} c$ & ${ }^{1} \mathrm{H}^{\mathrm{c}}$ & & & & & & \\
\hline $3 a$ & 167.6 & 161.5 & -10.24 & 236.9 & 227.2 & 256.4 & 3.0 & $<2.0$ & $<2.0$ \\
\hline $\mathbf{3 b}$ & 166.8 & 153.2 & -10.25 & 236.9 & 232.1 & 261.2 & 15.0 & $<2.0$ & $<2.0$ \\
\hline $3 c$ & 168.1 & 165.5 & -10.11 & 244.2 & 225.4 & 247.0 & $<2.0$ & $<2.0$ & $<2.0$ \\
\hline 5 & 167.3 & 167.3 & -10.15 & 239.9 & 228.1 & 260.3 & 3.0 & $<2.0$ & $<2.0$ \\
\hline 6 & $\mathrm{e}$ & & & & & & & & \\
\hline 7 & e & & & & & & & & \\
\hline 8 & 169.2 & 169.0 & -10.24 & 234.5 & 235.7 & 277.6 & $<2.0$ & $<2.0$ & $<2.0$ \\
\hline
\end{tabular}

${ }^{a} \mathrm{HRhL} \cap \mathrm{L}(\mathrm{CO})_{2}$ complexes prepared in toluene- $\mathrm{d}_{8} .{ }^{\mathrm{b}}{ }^{31} \mathrm{P}\left\{{ }^{1} \mathrm{H}\right\},{ }^{31} \mathrm{P}$, and ${ }^{1} \mathrm{H}$ spectra recorded in toluene-d $\mathrm{d}_{8}$ under atmospheric conditions. ${ }^{c}$ Chemical shifts $(\delta)$ in ppm. ${ }^{d}$ Coupling constants $(J)$ in hertz. e The HRhL $\cap(C O)_{2}$ complexes of $\mathbf{6}$ and $\mathbf{7}$ could not be synthesized in pure form.

Table 3. Hydroformylation of Styrene with $H R h L \cap L(C O)_{2}, L \cap L=3 a-c^{a}$

\begin{tabular}{|c|c|c|c|c|c|c|c|c|c|c|c|}
\hline \multirow[b]{2}{*}{ entry } & \multirow[b]{2}{*}{ ligand } & \multirow[b]{2}{*}{$\mathrm{T}\left({ }^{\circ} \mathrm{C}\right)$} & \multirow[b]{2}{*}{$\mathrm{pCO}$} & \multirow[b]{2}{*}{$\mathrm{pH}_{2}$} & \multirow[b]{2}{*}{ TOF $^{b}$} & \multicolumn{5}{|c|}{$\%$} & \multirow[b]{2}{*}{ abs conf } \\
\hline & & & & & & conve & isod & $\mathrm{n}^{\mathrm{e}}$ & $\mathrm{PhEt}^{\mathrm{f}}$ & $\overline{e^{g}}$ & \\
\hline 1 & $3 a$ & 50 & 10 & 10 & 130 & 52 & 84 & 13 & 3 & 60 & (S) \\
\hline 2 & $3 a$ & 40 & 10 & 10 & 45 & 21 & 89 & 8 & 3 & 67 & (S) \\
\hline 3 & $3 a$ & 25 & 10 & 10 & 9 & $26^{\mathrm{i}}$ & 93 & 5 & 2 & 87 & (S) \\
\hline 4 & $3 a$ & 25 & 10 & 20 & 8 & $69^{j}$ & 95 & 4 & 1 & 53 & (S) \\
\hline 5 & $3 b$ & 50 & 10 & 10 & 20 & 14 & 85 & 12 & 3 & 25 & (S) \\
\hline 6 & $3 b$ & 40 & 10 & 10 & 13 & 7 & 93 & 3 & 4 & 34 & (S) \\
\hline 7 & $3 \mathbf{b}$ & 25 & 10 & 10 & 2 & $7^{k}$ & 89 & 8 & 3 & 29 & (S) \\
\hline 8 & $3 c$ & 50 & 10 & 10 & 27 & 30 & 67 & 29 & 4 & 11 & (S) \\
\hline 9 & $3 c$ & 50 & 10 & 20 & 33 & 53 & 81 & 17 & 2 & 14 & (S) \\
\hline 10 & $3 c$ & 50 & 5 & 10 & 43 & 72 & 71 & 23 & 6 & 20 & (S) \\
\hline 11 & $3 c$ & 25 & 10 & 10 & 3 & 8 & 78 & 20 & 2 & 4 & (S) \\
\hline
\end{tabular}

a Styrene catalyst molar ratio is $1000, \mathrm{P}: \mathrm{Rh}$ molar ratio of 2.2. ${ }^{\mathrm{b}}$ TOF in mol styrene $(\mathrm{mol} \mathrm{Rh})^{-1} \mathrm{~h}^{-1}$ determined after $1 \mathrm{~h}$ reaction time by GC. ' Percent conversion of styrene. ${ }^{d}$ Selectivity to branched aldehyde. e Selectivity to linear aldehyde. ${ }^{f}$ Selectivity to ethyl benzene. ${ }^{g}$ Enantiomeric excess. ${ }^{\mathrm{h}}$ Absolute configuration. ${ }^{i}$ After $23 \mathrm{~h} .{ }^{\mathrm{j}}$ After $110 \mathrm{~h} .{ }^{k}$ After $24 \mathrm{~h} .{ }^{1}$ After $72 \mathrm{~h}$.

Table 4. Hydroformylation of Styrene with Diastereomeric HRhL $\cap L(C O)_{2}, L \cap L=4 a-c^{a}$

\begin{tabular}{|c|c|c|c|c|c|c|c|c|c|}
\hline \multirow[b]{2}{*}{ entry } & \multirow[b]{2}{*}{ ligand } & \multirow[b]{2}{*}{$\mathrm{T}\left({ }^{\circ} \mathrm{C}\right)$} & \multirow[b]{2}{*}{ TOF $^{b}$} & \multicolumn{5}{|c|}{$\%$} & \multirow{2}{*}{$\begin{array}{l}\text { abs } \\
\text { conf }\end{array}$} \\
\hline & & & & $\overline{\text { conv }^{c}}$ & iso & $\mathrm{n}^{\mathrm{e}}$ & $\mathrm{PhEt}^{f}$ & $\mathrm{ee}^{\mathrm{g}}$ & \\
\hline 12 & $4 a$ & 50 & 104 & 38 & 86 & 13 & 1 & 21 & (S) \\
\hline 13 & 4 & 25 & 14 & & 91 & 7 & 2 & 47 & (S) \\
\hline 14 & $4 b$ & 50 & 256 & 94 & 90 & 9 & 1 & 20 & (S) \\
\hline 15 & $4 b$ & 25 & 17 & $51^{j}$ & 94 & 6 & 0 & 28 & (S) \\
\hline 16 & 4c & 50 & 163 & 47 & 85 & 14 & 1 & 7 & (S) \\
\hline 17 & $4 c$ & 25 & 16 & $36^{j}$ & 93 & 6 & 1 & 15 & (S) \\
\hline 18 & $\mathbf{4} \mathbf{a}^{\mathrm{k}}$ & 25 & 11 & 26 & 94 & 6 & 0 & 57 & (S \\
\hline
\end{tabular}

a Styrene catalyst molar ratio is $1000, \mathrm{P}: \mathrm{Rh}$ molar ratio of 2.2 , $\mathrm{p}(\mathrm{CO})=\mathrm{p}\left(\mathrm{H}_{2}\right)=10$ bar. ${ }^{\mathrm{b}}$ TOF in mol styrene $(\mathrm{mol} \mathrm{Rh})^{-1} \mathrm{~h}^{-1}$ determined after $1 \mathrm{~h}$ by GC. c Percent conversion of styrene. d Selectivity to branched al dehyde. e Selectivity to linear aldehyde. ${ }^{f}$ Selectivity to ethyl benzene. ${ }^{g}$ Enantiomeric excess. ${ }^{\mathrm{h}}$ Absolute configuration. ${ }^{i}$ After $23 \mathrm{~h} .{ }^{\mathrm{j}}$ After $24 \mathrm{~h}$. ${ }^{\mathrm{k}} \mathrm{P}: \mathrm{Rh}$ molar ratio of 8.8 .

spectra. ${ }^{26}$ As is the case for $\mathbf{5}, \mathrm{HRh}(\mathbf{8})(\mathrm{CO})_{2}$ is formed quantitatively under standard reaction conditions. The 31P NMR spectrum of $\mathrm{HRh}(\mathbf{8})(\mathrm{CO})_{2}$ appeared as a double $A B$ signal caused by the intrinsically inequivalent phosphorus $\mathrm{P}_{1}$ and $\mathrm{P}_{2}\left({ }^{2} \mathrm{~J} \mathrm{P}_{\mathrm{P} 2}=278 \mathrm{~Hz},{ }^{1} \mathrm{~J} \mathrm{RhP} 1=234.2\right.$ $\mathrm{Hz}$, and ${ }^{1} \mathrm{~J} \mathrm{RhP}_{2}=235.1 \mathrm{~Hz}$ ). For diphosphite $\mathrm{L} \cap \mathrm{L}=\mathbf{4 a}$ $(\mathbf{4 a} \equiv \mathbf{5 : 7 : 8}=1: 1: 2)$ the $\mathrm{HRhL} \cap \mathrm{L}(\mathrm{CO})_{2}$ complex was prepared using a ligand to rhodium ratio of 4 . The $\mathrm{HRhL} \cap \mathrm{L}(\mathrm{CO})_{2}$ complex appeared as a diastereomeric mixture derived from $\mathbf{5}$ and $\mathbf{8}$ in a ratio of 2.65:1. No complexes derived from $\mathbf{7}$ were observed.

At low temperature $(213 \mathrm{~K})$, the ${ }^{31} \mathrm{P}$ NMR spectra of $\mathrm{HRhL} \cap \mathrm{L}(\mathrm{CO})_{2}$ complexes of $\mathbf{3 a}-\mathbf{c}$ and $\mathbf{5}$ appeared as sharp double $A B$ systems with spectral bandwidths $\left(\Delta \varpi_{1 / 2}\right)$ between 10 and $15 \mathrm{~Hz}$. The phosphorus atoms $\left(\mathrm{P}_{1}\right.$ and $\left.\mathrm{P}_{2}\right)$ showed different coupling constants with rhodium (see Table 2, ${ }^{1}$ RhP1 and ${ }^{1 /}$ RhP2; see Figure 3

(26) Traces of $\mathrm{H}_{2} \mathrm{O}$ can cause hydrolysis of the diphosphite ligand to $\mathrm{H}$-phosphonates ( $\delta$ between 0 and $15 \mathrm{ppm}$ ) under the reaction conditions.

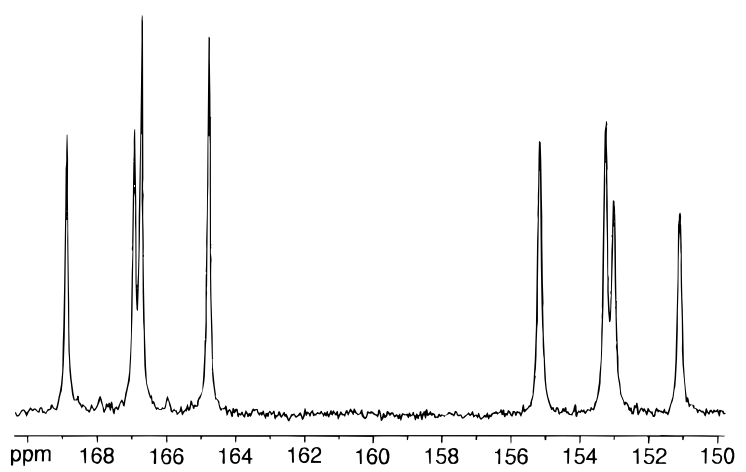

Figure 3. ${ }^{31 P} \mathrm{NMR}$ spectrum of $\mathrm{HRhL} \cap \mathrm{L}(\mathrm{CO})_{2}, \mathrm{~L} \cap \mathrm{L}=$ 3b $(\mathrm{T}=213 \mathrm{~K})$.

for the ${ }^{31 P}$ NMR spectrum of $\left.\mathrm{HRh}(\mathbf{3 b})(\mathrm{CO})_{2}\right)$. The lowtemperature ${ }^{31} \mathrm{P}$ NMR spectrum of $\mathrm{HRh}(\mathbf{8})(\mathrm{CO})_{2}$ closely resembled that observed at room temperature. The intrinsically different phosphorus atoms $P_{1}$ and $P_{2}$ give rise to double $A B$ resonances. All complexes showed phosphorus-phosphorus coupling constants ( ( $\mathrm{J}$ P1P2) between 247 and $261 \mathrm{~Hz}$. The hydride signal appeared as a broadened doublet because of the coupling with rhodium ( $1 \mathrm{~J} \mathrm{RhH}$ between 3 and $15 \mathrm{~Hz}$ ). The phosphorushydride couplings ( ${ }^{2} \mathrm{~J} \mathrm{P}_{1 \mathrm{H}}$ and ${ }^{2} \mathrm{P}_{\mathrm{P}} \mathrm{H}$ ) were very small $(<2$ $\mathrm{Hz}$ ). The coupling constants are indicative of trigonal bipyramidal hydridorhodium species with bis-equatorially coordinating diphosphites. ${ }^{10}$

Hydroformylation Experiments. Diphosphites 3-8, with sterically demanding bis o-trialkylsilyl substituents, were used in the rhodium-catalyzed asymmetric hydroformylation. After standard catalyst preparation conditions, styrene was hydroformylated at various reaction conditions. The results are given in Tables 3-5. For ligand $\mathbf{3 a}$ (Table 3, entries 1-4), the reaction rate decreases with temperature. A temperature decrease from 50 to $25{ }^{\circ} \mathrm{C}$ reduces the initial turnover 
Table 5. Hydroformylation with $\mathrm{HRhL} \cap \mathrm{L}(\mathrm{CO})_{2}$, $\mathbf{L} \cap \mathbf{L}=\mathbf{5}-\mathbf{8}^{\mathrm{a}}$

\begin{tabular}{|c|c|c|c|c|c|c|c|c|c|}
\hline \multirow[b]{2}{*}{ entry } & \multirow[b]{2}{*}{ ligand } & \multirow[b]{2}{*}{$\mathrm{T}\left({ }^{\circ} \mathrm{C}\right)$} & \multirow[b]{2}{*}{ TOF $^{b}$} & \multicolumn{5}{|c|}{$\%$} & \multirow{2}{*}{$\begin{array}{l}\text { abs } \\
\text { confh }\end{array}$} \\
\hline & & & & $\overline{\text { conv }^{c}}$ & iso $^{d}$ & $\mathrm{n}^{\mathrm{e}}$ & PhEt $^{f}$ & $\overline{e e^{g}}$ & \\
\hline 19 & 5 & 50 & 133 & 43 & 83 & 13 & 4 & 58 & (S) \\
\hline 20 & 5 & 25 & 17 & $38^{i}$ & 88 & 8 & 4 & 69 & (S) \\
\hline 21 & 5 & 15 & 11 & $12^{i}$ & 92 & 6 & 2 & 86 & (S) \\
\hline 22 & 6 & 50 & 281 & 98 & 89 & 10 & 1 & 8 & (R) \\
\hline 23 & 6 & 40 & 259 & 89 & 91 & 8 & 1 & 18 & (R) \\
\hline 24 & 6 & 25 & 45 & 21 & 94 & 5 & 1 & 40 & (R) \\
\hline 25 & 7 & 50 & 387 & 99 & 87 & 10 & 3 & 12 & (S) \\
\hline 26 & 7 & 40 & 186 & 99 & 92 & 6 & 2 & 30 & (S) \\
\hline 27 & 7 & 25 & 28 & 18 & 95 & 4 & 1 & 38 & (S) \\
\hline 28 & 8 & 50 & 12 & 36 & 87 & 11 & 2 & 16 & (S) \\
\hline 29 & 8 & 40 & 6 & 25 & 88 & 11 & 1 & 18 & (S) \\
\hline 30 & 8 & 25 & 4 & 2 & 91 & 8 & 1 & 23 & (S) \\
\hline
\end{tabular}

a Styrene catalyst molar ratio is $1000, p(C O)=p\left(H_{2}\right)=10$ bar, $\mathrm{P}: \mathrm{Rh}$ ratio 2.2. ${ }^{\mathrm{b}}$ TOF in mol styrene $(\mathrm{mol} \mathrm{Rh})^{-1} \mathrm{~h}^{-1}$ determined after $1 \mathrm{~h}$ by GC. ' Percent conversion of styrene after $5 \mathrm{~h}$. d Selectivity to branched aldehyde. e Selectivity to linear aldehyde. ${ }^{f}$ Selectivity to ethyl benzene. ${ }^{g}$ Enantiomeric excess. ${ }^{\mathrm{h}}$ Absolute configuration. i After $24 \mathrm{~h}$.

frequencies from 130 to $9 \mathrm{~mol} \mathrm{~mol}^{-1} \mathrm{~h}^{-1}$. Enantiomeric excesses of $60-87 \%$ were found using ligand $3 a$.

The effects of the steric bulk of ligands $\mathbf{3}$ on reaction rates and the asymmetric induction were examined. The rhodium catalyst derived from ligand $\mathbf{3 b}$, with bulky triethylsilyl substituents at the ortho positions, resulted in a very low reaction rate (entries 5-7).

Comparably low reaction rates were found at $50{ }^{\circ} \mathrm{C}$ with the tert-butyldimethyl analogue $\mathbf{3 c}$ (entry 8 ). The reaction was accelerated by an increased partial pressure of hydrogen (entry 9) and decreased partial pressure of CO (entry 10). At relatively long reaction time the enantiomeric excess dropped to $4 \%$ (entry 11 ).

The results of the asymmetric hydroformylation of styrene with ligands $\mathbf{4 a -}-\mathbf{c}$ are given in Table 4 . These ligands exist as mixtures of diastereomers and therefore mixtures of hydridorhodium catalysts are formed.

At $25^{\circ} \mathrm{C}$ high proportions of branched aldehyde were found $(91-93 \%)$. At $50{ }^{\circ} \mathrm{C}$ high turnover frequencies were observed for $\mathrm{HRhL} \cap \mathrm{L}(\mathrm{CO})_{2}$ complexes of $\mathbf{4 b}$ (entry 14) and 4c (entry 16). The highest enantiosel ectivity (47\%, entry 13 ) is again obtained using ligands with trimethylsilyl substituents at the ortho positions of the bisnaphthol groups. This enantiomeric excess could be improved to $57 \%$ using a larger excess of ligand $4 \mathbf{4 a}$ (P: $\mathrm{Rh}$ ratio of 8.8 , entry 18 ).

Diastereomerically pure ligands 5-8 having fixed absolute configurations have also been used in the asymmetric hydroformylation of styrene. The results are given in Table 5 .

The results obtained using 5 (entries 19-21) resemble strongly those reported for the bisphenol analogue 3a (Table 3, entries 1-3). In the temperature range of 50$15{ }^{\circ} \mathrm{C}$ the catalytic system shows almost identical reaction rates and regio- and enantioselectivities.

Hydridorhodium complexes of the enantiomeric ligands 6 and 7 show high catalytic activities, al beit with low asymmetric induction (entries 22-27). Hydroformylati on using ligand 8 results in both low catalytic activity and low enantioselectivity (entries 28-30).

\section{Discussion}

For the synthesis of 3,3'-bis(trimethylsilyl)-substituted 2,2'-bisphenols and racemic (R/S)-( \pm -), enantiomerically pure (S)-(-)-, and (R)-(+)-2,2'-bisnaphthols, ethyl

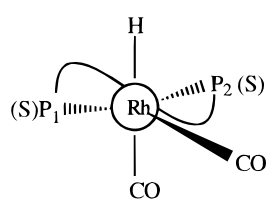

A

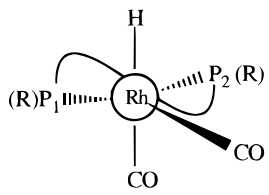

D

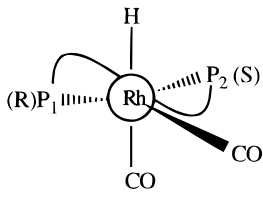

B

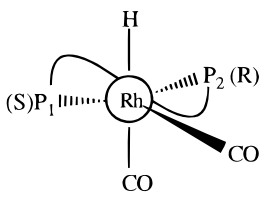

C
Figure 4. Diastereomeric $\mathrm{HRhL} \cap \mathrm{L}(\mathrm{CO})_{2}$ complexes (AD). The indicators (R) and (S) refer to axial chirality in the biaryl substituents.

vinyl ether (EVE) was successfully applied as protecting group. Thus, the reaction route was considerably shortened compared with the method reported by Yamamoto et al. ${ }^{17 a}$

The different behavior of ligands $\mathbf{3}$ and $\mathbf{5}-\mathbf{8}$ in the formation of the $\mathrm{HRhL} \cap \mathrm{L}(\mathrm{CO})_{2}$ complexes clearly demonstrates that both the absolute configuration of the 2,4pentanediol ligand backbone and the chiral bisnaphthol substituents determine the stability and catalytic performance of the rhodium complexes. Well-defined stable complexes could be prepared with ligands $\mathbf{3}, \mathbf{5}$, and $\mathbf{8}$, whereas ligands $\mathbf{6}$ and $\mathbf{7}$ lead to undefined mixtures of complexes and ligand decomposition. Using an excess of the statistical mixture of diastereomers $\mathbf{4 a}$ resulted in the formation of complexes derived from $\mathbf{5}$ and $\mathbf{8}$ only. Despite the 2-fold higher concentration of $\mathbf{8}$, the complex derived from ligand $\mathbf{5}$ proved to be the most stable one, as was concluded from its preferential formation (73\%) observed by ${ }^{31} \mathrm{P}$ and ${ }^{1} \mathrm{H}$ NMR.

Since the phosphorus atoms have different orientations toward the axial hydride and carbon monoxide ligands, they are inequivalent in the $C_{1}$ symmetrical $\mathrm{HRhL} \cap \mathrm{L}(\mathrm{CO})_{2}$ complexes derived from $\mathbf{3 a}-\mathbf{c}$ and $\mathbf{5}$. This means that four diastereomeric hydridorhodium diphosphite dicarbonyl complexes (Figure 4, A-D) can be formed. However, simple doublets are observed in the 31P NMR spectra ( $T=293 \mathrm{~K}$ ) of trigonal bipyramidal $\mathrm{HRhL} \cap \mathrm{L}(\mathrm{CO})_{2}$ complexes of $\mathbf{3 a}-\mathbf{c}$ and $\mathbf{5}$, which suggests a fast fluxional processes on the NMR time scale exchanging the phosphorus atoms in the complexes. Evidence for such an exchange process in $\mathrm{HRhL} \cap \mathrm{L}(\mathrm{CO})_{2}$ complexes of $\mathbf{3 a}-\mathbf{c}$ and $\mathbf{5}$ was obtained from the lowtemperature ${ }^{31 P}$ NMR spectra. At $213 \mathrm{~K}$ sharp double $A B$ systems were observed, which indicates that the slow-exchange region was reached. Since the phosphorus atoms $\mathrm{P}_{1}$ and $\mathrm{P}_{2}$ of $\mathrm{HRh}(\mathbf{8})(\mathrm{CO})_{2}$ are intrinsically different, the low-temperature ${ }^{31} \mathrm{P}$ NMR spectrum closely resembled that observed at room temperature. The observed coupling constants for all complexes are indicative of trigonal bipyramidal hydridorhodium species with bis-equatorially coordinating diphosphites. ${ }^{10}$

The possibility that the phosphorus chemical shifts of the four diastereomeric $\mathrm{HRhL} \cap \mathrm{L}(\mathrm{CO})_{2}$ complexes (AD) derived from ligands $\mathbf{3 a}-\mathbf{c}$ accidentally coincide was excluded on the basis of the ${ }^{31} \mathrm{P}$ and ${ }^{1} \mathrm{H}$ NMR spectra of the diastereomeric complexes $\mathrm{HRh}(5)(\mathrm{CO})_{2}$ and $\mathrm{HRh}$ - 
(8) $(\mathrm{CO})_{2}$. Complexes of $\mathbf{5}$ and $\mathbf{8}$, schematically represented as structures $\mathbf{A}$ and $\mathbf{C}$, respectively, cannot undergo inversion around the binaphthyl bonds and they exhibit different ${ }^{31} \mathrm{P}$ NMR spectra (see Tables 1 and 2). The low-temperature 31P NMR spectra of $\mathrm{HRhL} \cap \mathrm{L}(\mathrm{CO})_{2}, \mathrm{~L} \cap \mathrm{L}=\mathbf{3 a}-\mathbf{c}$, show a large resemblance with the low-temperature ${ }^{31} \mathrm{P}$ NMR spectra of $\mathrm{HRh}(\mathbf{5})$ $(\mathrm{CO})_{2}$. These results make it plausible that $\mathrm{HRhL} \cap \mathrm{L}$ $(\mathrm{CO})_{2}$ complexes containing ligands $\mathbf{3 a}-\mathbf{c}$, which can freely interchange around the biphenyl linkage, exist as one particular diastereomer in the $\mathrm{HRhL} \cap \mathrm{L}(\mathrm{CO})_{2}$ complex. However, it should be kept in mind that the dihedral angles of the bisphenol moieties can differ from the more rigid bisnaphthols which can also have its impact on the characteristics of the phosphorus.

Rhodium-catalyzed hydroformylation of styrene with 3 as ligand results in high enantiomeric excesses up to $87 \%$. For comparison, bulky tert-butyl groups at the ortho positions gave rise to lower enantiomeric excesses (up to $68 \%$ ) under the same reaction conditions. ${ }^{10 \mathrm{~b}}$ At longer reaction times $(110 \mathrm{~h}$ ) the enantiomeric excess dropped to $53 \%$, probably caused by catalyst decomposition. The increased branched (iso) to normal aldehyde ratios observed at lower reaction temperatures and higher $\mathrm{CO}$ and $\mathrm{H}_{2}$ pressures (entries 3 vs 4 and 8 vs 9 ) are generally explained by a decreased $\beta$ - $\mathrm{H}$ elimination of the branched rhodium alkyl intermediate. ${ }^{27,28}$

The introduction of larger substituents at the ortho position showed the expected trend of steric bulkiness on the reaction rate. The reaction rates decreased with an increase in steric bulk of the ortho substituents; i.e., $\mathrm{C}\left(\mathrm{CH}_{3}\right)_{3}{ }^{29}<\mathrm{Si}\left(\mathrm{CH}_{3}\right)_{3}<\mathrm{Si}(\mathrm{t}-\mathrm{Bu})\left(\mathrm{CH}_{3}\right)_{2}<\mathrm{Si}\left(\mathrm{CH}_{2} \mathrm{CH}_{3}\right)_{3}$ (see turnover frequencies at $50{ }^{\circ} \mathrm{C}$, entries 1,5 , and 8 , Table 3). However, the bulky $\mathrm{Si}(\mathrm{t}-\mathrm{Bu})\left(\mathrm{CH}_{3}\right)_{2^{-}}$and $\mathrm{Si}\left(\mathrm{CH}_{2} \mathrm{CH}_{3}\right)_{3}$-containing ligands $\mathbf{3 b}, \mathbf{c}$ did not result in an improvement of the enantiomeric excess. The optimal steric bulk in the ortho position seems to be obtained with trimethylsilyl substituents. Therefore, the trimethylsilyl group was also used for the optically pure bisnaphthol substituents in ligands 5-8.

From the results in Table 5 it can be concluded that the absolute configuration around the binaphthyl axis has a dramatic effect on the catalyst performance. When both the pentane backbone and the binaphthyl substituents have all S (6) or all R (7) configuration, a low enantiomeric excess is observed. In situ NMR studies showed that the $\mathrm{HRhL} \cap \mathrm{L}(\mathrm{CO})_{2}$ complexes of $\mathbf{6}$ and 7 could not selectively be synthesized. The coexistence of highly active rhodium species, in which the ligands coordinate as monodentates, ${ }^{30}$ is held responsible for the low enantiosel ectivity and relatively high reaction rates observed.

Ligands $\mathbf{5}$ and $\mathbf{8}$ both form stable rhodium complexes, but only diastereomer $\mathbf{5}$ shows chiral cooperativity and

(27) (a) Lazzaroni, R.; Raffaelli, A.; Settambolo, R.; Bertozzi, S.; Vitulli, G. J. Mol. Catal. 1989, 50, 1. (b) U cello-Baretta, G.; Lazzaroni, R.; Settambolo, R.; Salvadori, P. J . J . Organometal. Chem. 1991, 417, 111.

(28) Van Rooy, A.; Kamer, P. C. J .; van Leeuwen, P. W. N. M.; Goubitz, K.; Fraanje, J .; Veldman, N.; Spek, A. L. Organometallics 1996, 15, 835.

(29) Comparison of data should be interpreted with care since the reaction conditions for the $\mathrm{C}\left(\mathrm{CH}_{3}\right)_{3}$-substituted ligand are not the same However, the reported TOF of $166 \mathrm{~mol} \mathrm{~mol}^{-1} \mathrm{~h}^{-1}$ at $40{ }^{\circ} \mathrm{C}$ in ref $11 \mathrm{~b}$ Table 1 exceeds the TOFs reported for the trialkylsilyl-substituted analogues at $50{ }^{\circ} \mathrm{C}$, which justifies the comparison of TOFs.

(30) van Rooy, A.; Orij, E. N.; Kamer, P. C. J .; van Leeuwen, P. W. N. M. Organometallics 1995, 14, 34. consequently gives a high ee. The results obtained for 5 resemble those observed for $\mathbf{3 a}$.

These results strongly support the conclusion that fast interchanging atropisomers of $\mathbf{3 a}$ adopt predominantly the $(S, 2 R, 4 R, S)$ conformation in the $\mathrm{HRh}(3 \mathrm{a})(\mathrm{CO})_{2}$ complex, which is in agreement with the observed lowtemperature N MR spectrum; i.e., resonances bel onging to competitive diastereomeric hydridorhodium complexes could not be detected in any appreciable amounts. Further evidence for the existence of single diastereomeric $\mathrm{HRhL} \cap \mathrm{L}(\mathrm{CO})_{2}$ complexes containing ligands $\mathbf{3 a - c}$ can be derived from the results found for $\mathbf{4 a}$ and $\mathbf{5}$ (Tables 4 and 5). Hydroformylation using $\mathbf{4 a}$, which consists of three diastereomers, resulted in lower asymmetric inductions (entries 12 and 13) compared with the results obtained with the single isomer $\mathbf{5}$ (entries 19 and 20). The turnover frequency of the hydroformylation reaction using ligand $\mathbf{4 a}$ equals the average of a statistical mixture of $\mathbf{5}, \mathbf{7}$, and $\mathbf{8}$. $^{31}$ Also, the observed enantiomeric excess corresponds to the average value, when the different reaction rates of the diastereomeric complexes are taken into consideration. ${ }^{31 P}$ NMR analysis of the rhodium complexes derived from $\mathbf{4 a}$ showed that the most stable complex is formed by ligand $\mathbf{5}$, the one that also induces the highest enantioselectivity. Using a 4-fold excess of $\mathbf{4 a}$, a mixture of rhodium hydride complexes derived only from $\mathbf{5}$ and $\mathbf{8}$ are formed in a ratio of 2.65:1. This explains the increased enantiomeric excess when 4.4 equiv of $\mathbf{4 a}$ is used (entry 18). The observed turnover frequency of $11 \mathrm{~mol} \mathrm{~mol}^{-1} \mathrm{~h}^{-1}$ and ee of $57 \%$ are in agreement with preferred complexation of $\mathbf{5}$ compared to $\mathbf{8}$. Since no rhodium complexes derived from $\mathbf{7}$ are observed, the ee increases with increasing ligand to rhodium ratio. Likewise, it seems reasonable to assume that ligand $\mathbf{3 a}$, with adaptable conformations in the diaryl substituents, preferentially forms the most stable catalyst complex that also induces the highest enantiosel ectivity.

\section{Conclusions}

Variation of the ortho substituents on the bisphenol or bisnaphthol moieties in di phosphites 3-8 has a large effect on the asymmetric induction of the rhodiumcatalyzed asymmetric hydroformylation of styrene. The highest enantiomeric excesses were found using trimethylsilyl substituents both for ligands $\mathbf{3}$ and $\mathbf{4}$. Application of the diastereomerically pure ligands 5-8 clearly showed chiral cooperativity of the central backbone and the biaryl substituents. The highest ee of $86 \%$ using the diastereomer $\mathbf{5}$ is in the same range as the ee found for 3a, which has rotational freedom around the biaryl axis.

The formation of only one diastereomer of hydridorhodium diphosphite dicarbonyl complexes [HRhL $\cap$ $(\mathrm{CO})_{2}$ ] of ligands $\mathbf{3 a}-\mathbf{c}$ was observed in ${ }^{31} \mathrm{P}$ NMR spectra. Apparently, the low-energy barrier for interconversion in atropisomers $\mathbf{3 a}-\mathbf{c}$ results in the formation of the most stable conformation in $\mathrm{HRhL} \cap \mathrm{L}(\mathrm{CO})_{2}$ complexes. The high enantioselectivity of $87 \%$ found using ligand 3a suggests that the preferentially formed

(31) The formation of the $\mathrm{HRhL} \cap \mathrm{L}(\mathrm{CO})_{2}$ complex using 1 equiv of ligand $\mathbf{4 a}$ results in the formation of a statistical mixture of diasteroisomeric complexes (ratio 5:7:8 = 1:1:2). At $25^{\circ} \mathrm{C}$ this gives a calculated TOF of $(1 \times 17+1 \times 28+2 \times 4) / 4=13 \mathrm{~mol} \mathrm{~mol}^{-1} \mathrm{~h}^{-1}$, whereas the observed value for $4 a$ was $14 \mathrm{~mol} \mathrm{~mol}^{-1} \mathrm{~h}^{-1}$. The calculated ee amounts to $(1 \times 17 \times 69+1 \times 28 \times 38+2 \times 4 \times 23) /(1 \times 17+1$ $\times 28+2 \times 4)=46 \%$, whereas the observed value was $47 \%$. 
complex has the required conformation for optimal chiral cooperativity that induces the highest ee, as was observed for the complex derived from diastereomerically pure ligand $\mathbf{5}$.

\section{Experimental Section}

General Considerations. Chemicals were obtained from Acros Chimica and Aldrich Chemical Co. All reactions were carried out in oven-dried glasswork using standard Schlenk techniques under an atmosphere of argon. Toluene was distilled from sodium/benzophenone. Triethyl amine and $\mathrm{CH}_{2-}$ $\mathrm{Cl}_{2}$ were distilled from $\mathrm{CaH}_{2}$. $\mathrm{PCl}_{3}$ was distilled before use. For column chromatography silica gel 60 (230-400 mesh) purchased from Merck was used. Melting points were determined on a Gallenkamp MFB-595 melting point apparatus in open capillaries and are uncorrected. NMR spectra were obtained on a Bruker AMX 300 spectrometer. ${ }^{31} \mathrm{P}$ and ${ }^{13} \mathrm{C}$ spectra were measured ${ }^{\mathrm{H}} \mathrm{H}$-decoupled unless otherwise stated. TMS was used as a standard for ${ }^{1} \mathrm{H}$ and ${ }^{13} \mathrm{C} N M R$ and $\mathrm{H}_{3} \mathrm{PO}_{4}$ for ${ }^{31}$ P NMR. I nfrared spectra were recorded on a Nicolet 510 FT-IR spectrophotometer. Optical rotations were measured on a Perkin-Elmer 241 polarimeter at room temperature (22 $\left.{ }^{\circ} \mathrm{C}\right)$. Gas chromatographic analyses were run on an Interscience HR GC Mega 2 apparatus (split/splitless injector, J \&W Scientific, DB1 $30 \mathrm{~m}$ column, film thickness $3.0 \mu \mathrm{m}$, carrier gas $70 \mathrm{kPa} H \mathrm{He}$, FID detector) equipped with a Hewlett-Packard Data system (Chrom-Card). Enantiomeric excesses were measured after reduction of the aldehydes with $\mathrm{NaBH}_{4}$ to the corresponding alcohols on a Carlo Erba Vega 6000 gas chromatograph (split/splitless injector, SGE $50 \mathrm{~m}$ chiral $\beta$-cyclodextrin column, FID detector, equipped with a Shimadzu C-R $5 \mathrm{~A}$ integrator). Mass spectra were measured on a HP 5890/ 5971 GC-mass spectrometer. Hydroformylation reactions were carried out in a homemade $200 \mathrm{~mL}$ stainless steel autoclave. Syn gas 3.0 was purchased from Praxair. Elemental analyses were performed by the Department of MicroAnalyses at the University of Groningen and on a Elementar Vario EL analyzer from FOSS-electric Benelux. 3,3'-Dibromo2,2'-dimethoxy-1,1'-biphenyl was prepared according to a literature procedure. ${ }^{32}$ FAB-mass spectra were recorded by the Institute of Mass Spectroscopy of the University of Amsterdam on a J EOL J MS- SX/SX102A.

Catalysis. In a typical experiment, the autoclave was dried under reduced pressure at $50^{\circ} \mathrm{C}$ for $1 \mathrm{~h}$ and filled with Rh(acac) $(\mathrm{CO})_{2}(0.020 \mathrm{mmol}, 5 \mathrm{~mL}$ of a $4.0 \mathrm{mM}$ stock solution in toluene), diphosphite ligand $(0.022 \mathrm{mmol}, \mathrm{P} / \mathrm{Rh}$ ratio of 2.2$)$, and toluene $(5.0 \mathrm{~mL})$. Subsequently the autoclave was purged three times with syn gas $\left(\mathrm{CO}: \mathrm{H}_{2}=1: 1\right)$ and pressurized to the appropriate initial pressure. After heating the autoclave to the reaction temperature, the reaction mixture was stirred for $15 \mathrm{~h}$ to form the active catalyst. Styrene $(2.29 \mathrm{~mL}, 20.0 \mathrm{mmol}$, filtered over neutral, activated aluminum oxide), the internal standard decane $(5.0 \mathrm{mmol}, 0.98 \mathrm{~mL}$, dried on magnesium sulfate), and toluene $(6.73 \mathrm{~mL}$, total solvent volume $20 \mathrm{~mL}$ ) were brought into the autoclave. During the reaction several samples were taken from the reaction vessel. After the desired reaction time the autoclave was cooled, depressurized, and vented with nitrogen. The reaction mixture was directly vacuum distilled to remove the catalyst and analyzed by GC. A sample of the reaction mixture was dissolved in ethanol. Sodium borohydride was added and the reaction mixture was stirred for $90 \mathrm{~min}$ at room temperature. After quenching the reaction mixture with water, the mixture was extracted two times with ethyl acetate/hexane (1/1). The organic layers were combined and dried on magnesium sulfate. About $20 \mu \mathrm{L}$ of reduced reaction mixture was dissolved in ethanol $(10 \mathrm{~mL})$ and analyzed by GC for determination of the enantiomeric excess.

Preparation of $\mathbf{H R h L} \cap \mathbf{L}(\mathbf{C O})_{2}$ Complexes. In a typical experiment a $5 \mathrm{~mL}$ vessel was filled with $\mathrm{Rh}(\mathrm{acac})(\mathrm{CO})_{2}(0.0291$

(32) Lingenfelter, D. S.; Helgeson, R. C.; Cram, D. J . J . Org. Chem. 1981, 46, 393. $\mathrm{mmol}$ ), diphosphite ligand $(0.0291 \mathrm{mmol})$, and toluene- $\mathrm{d}_{8}$ ( 1 $\mathrm{mL}$ ) and placed into the autoclave. Subsequently the autoclave was purged three times with syn gas (CO: $\left.\mathrm{H}_{2}=1: 1\right)$ and pressurized to the appropriate pressure (15-20 bar). After a reaction time of $15 \mathrm{~h}$ at $50{ }^{\circ} \mathrm{C}$, the autoclave was cooled and depressurized. Shorter reaction times resulted in incomplete conversions and gave intermediate $\mathrm{RhL} \cap \mathrm{L}$ (acac) and $\mathrm{RhL} \cap \mathrm{L}$ (acac)(CO) species with characteristic rhodium-phosphorus coupling constants of about $300 \mathrm{~Hz}$. ${ }^{6,7,10 \mathrm{~b}}$ Under atmospheric conditions NMR tubes were filled and immediately analyzed. No decomposition of $\mathrm{HRhL} \cap \mathrm{L}(\mathrm{CO})_{2}$ could be observed during analysis. Typical IR data are given for complexes of $\mathbf{3 a}$ (RhCO, 2066, 2016; Rh-H, $1995 \mathrm{~cm}^{-1}$ ) and 3c (Rh-CO, 2071, 2016; $\left.\mathrm{Rh}-\mathrm{H}, 1982 \mathrm{~cm}^{-1}\right){ }^{10 a, b}$

3,3'-Dibromo-2,2'-bisphenol. This compound was prepared according to a modified literature procedure. ${ }^{33} 3,3^{\prime}$ Dibromo-2,2'-dimethoxy-1,1'-bi phenyl (40 mmol, $14.86 \mathrm{~g}$ ) was dissolved in $57 \% \mathrm{HI}(194 \mathrm{mmol}, 43.52 \mathrm{~g})$ and stirred for $4 \mathrm{~h}$ at reflux temperature. An additional amount of $57 \% \mathrm{HI}(97$ mmol) was added and the reaction mixture was refluxed overnight. The dark brown reaction mixture was extracted with $\mathrm{CH}_{2} \mathrm{Cl}_{2}(4 \times 75 \mathrm{~mL})$. The organic layers were combined and washed with $200 \mathrm{~mL}(0.1 \mathrm{M}) \mathrm{NaS}_{2} \mathrm{O}_{3}$ to yield a colorless organic phase. The organic layer was dried on $\mathrm{MgSO}_{4}$. Evaporation of the solvent gave $12 \mathrm{~g}$ of crude product which was purified by column chromatography (10\% EtOAc/toluene $\left.(v / v), R_{f}=0.40\right)$. Yield: $74 \%(29.6 \mathrm{mmol}, 10.18 \mathrm{~g})$. M $\mathrm{Mp:} 124-$ $125^{\circ} \mathrm{C} .{ }^{13} \mathrm{C} \mathrm{NMR}\left(\mathrm{CDCl}_{3}\right): \delta 149.3$ (C arom), 132.2 (CH arom), 130.9 (CH arom), 125.4 (C arom), 121.8 (CH arom), 111.2 (C arom). ${ }^{1} \mathrm{H} \mathrm{NMR}\left(\mathrm{CDCl}_{3}\right): \delta 7.55\left(\mathrm{dd}, 2 \mathrm{H}\right.$, arom, ${ }^{3} \mathrm{~J}=7.9 \mathrm{~Hz}$, $4 \mathrm{~J}=1.6 \mathrm{~Hz}), 7.23(\mathrm{dd}, 2 \mathrm{H}$, arom, $3 \mathrm{~J}=7.7 \mathrm{~Hz}, 4 \mathrm{~J}=1.6 \mathrm{~Hz})$, $6.92(\mathrm{dd}, 2 \mathrm{H}$, arom, $3 \mathrm{~J}=7.9 \mathrm{~Hz}, 3 \mathrm{~J}=7.7 \mathrm{~Hz}), 5.92(\mathrm{~s}, 2 \mathrm{H}, \mathrm{OH}$. Anal. Calcd for $\mathrm{C}_{12} \mathrm{H}_{8} \mathrm{O}_{2} \mathrm{Br}_{2}$ : C, 41.90; $\mathrm{H}, 2.35$. Found: $\mathrm{C}$, 42.12; $\mathrm{H}, 2.50$. $\mathrm{MS}: \mathrm{m} / \mathrm{z}=344\left(\mathrm{M}^{+}\right)$.

2,2'-Bis(1-ethoxyethoxy)-1,1'-biphenyl. This compound was prepared in situ according to a literature procedure. ${ }^{19} 2,2^{\prime}-$ Bisphenol $(8.0 \mathrm{mmol}, 1.49 \mathrm{~g})$ was azeotropically dried with toluene $(3 \times 1 \mathrm{~mL})$ and dissolved in a solution of pyridinium p-toluenesulfonate $(0.8 \mathrm{mmol}, 0.21 \mathrm{~g})$ in $\mathrm{CH}_{2} \mathrm{Cl}_{2}(65 \mathrm{~mL})$. Ethyl vinyl ether $(24.0 \mathrm{mmol}, 2.29 \mathrm{~mL})$ was slowly added at room temperature and the mixture stirred for $72 \mathrm{~h}$. The reaction mixture was poured into water and extracted with diethyl ether. The organic phase was washed with brine and dried on $\mathrm{MgSO}_{4}$. Evaporation of the solvent gave 2,2'-bis(1-ethoxyethoxy)-1,1'-biphenyl as a diastereomeric mixture in quantitative yield. The product was used in the subsequent reactions without further purification.

3,3'-Bis(trimethylsilyl)-2,2 -bis(1-ethoxyethoxy)-1,1'-biphenyl. 2,2'-Bis(1-ethoxyethoxy)-1,1'-biphenyl (8.0 mmol) was azeotropically dried with toluene $(3 \times 1 \mathrm{~mL})$ and dissol ved in $\mathrm{Et}_{2} \mathrm{O}(25 \mathrm{~mL})$. A solution of $\mathrm{n}$-BuLi in hexane $(32 \mathrm{mmol}, 2.5$ $\mathrm{M}, 12.8 \mathrm{~mL}$ ) was slowly added at room temperature and the reaction mixture was stirred overnight. The white precipitate was cautiously washed with hexanes $(2 \times 5 \mathrm{~mL})$ and dissolved in THF $(25 \mathrm{~mL})$. At $-78^{\circ} \mathrm{C}$ a solution of $\mathrm{SiMe}_{3} \mathrm{Cl}(16 \mathrm{mmol}$, $2.04 \mathrm{~mL})$ in THF $(20 \mathrm{~mL})$ was added slowly. The reaction mixture was warmed to room temperature overnight. The reaction mixture was quenched with $\mathrm{H}_{2} \mathrm{O}(25 \mathrm{~mL})$ and extracted with $\mathrm{Et}_{2} \mathrm{O}(3 \times 25 \mathrm{~mL})$. The organic layers were combined, dried on $\mathrm{MgSO}_{4}$, and evaporated to dryness. The product was purified by column chromatography (2\% EtOAcl PE $\left.60-80{ }^{\circ} \mathrm{C}(\mathrm{v} / \mathrm{v}), \mathrm{R}_{\mathrm{f}}=0.40\right)$. Yield: $42 \%(3.35 \mathrm{mmol}, 1.59 \mathrm{~g})$ of a yellow oil. ${ }^{1 H} \mathrm{NMR}\left(\mathrm{CDCl}_{3}\right): \delta 7.43(\mathrm{dd}, 3 \mathrm{~J}=7.2 \mathrm{~Hz}, 4 \mathrm{~J}$ $=1.7 \mathrm{~Hz}, 2 \mathrm{H}$, arom), $7.27(\mathrm{~m}, 2 \mathrm{H}$, arom), 7.12 (dd, $3 \mathrm{~J}=14 \mathrm{~Hz}$, 3) $=6.3 \mathrm{~Hz}, 2 \mathrm{H}$, arom), $4.63\left(\mathrm{q}, 3 \mathrm{~J}=5.0 \mathrm{~Hz}, 2 \mathrm{H}, \mathrm{CH}_{3} \mathrm{CH}_{2}\right)$, $\left.3.73\left(q,{ }^{3}\right)=7.1 \mathrm{~Hz}, 2 \mathrm{H}, \mathrm{CH}_{3} \mathrm{CH}_{2}\right), 3.14(\mathrm{~m}, \mathrm{H}, \mathrm{CH}), 2.94(\mathrm{~m}$, $\mathrm{H}, \mathrm{CH}), 1.16\left(\mathrm{~d}, 3 \mathrm{~J}=5.0 \mathrm{~Hz}, 6 \mathrm{H}, \mathrm{CH}_{3}\right), 0.86(\mathrm{~d}, 3 \mathrm{~J}=6.9 \mathrm{~Hz}$, $\left.6 \mathrm{H}, \mathrm{CH}_{3}\right) 0.35\left(\mathrm{~m}, 18 \mathrm{H}, \mathrm{Si}\left(\mathrm{CH}_{3}\right)_{3}\right)$.

3,3'-Bis(trimethylsilyl)-2,2'-bisphenol (1a). 3,3'-Bis(trimethylsilyl)-2,2'-bis(1-ethoxyethoxy)-1,1'-bi phenyl (3.36 mmol) was deprotected with pyridinium $\mathrm{p}$-toluenesulfonate according to a literature procedure. ${ }^{19}$ The product was purified by column chromatography $\left(7 \%\right.$ EtOAc/PE $60-80{ }^{\circ} \mathrm{C}(\mathrm{v} / \mathrm{v}), \mathrm{R}_{\mathrm{f}}=$ 
0.42). Mp: $99-100{ }^{\circ} \mathrm{C}$. Yield: $75 \%(2.52 \mathrm{mmol}, 0.83 \mathrm{~g})$ of a white powder. ${ }^{1} \mathrm{H} \mathrm{NMR}\left(\mathrm{CDCl}_{3}\right): \delta 7.45\left(\mathrm{dd},{ }^{3} \mathrm{~J}=7.2 \mathrm{~Hz},{ }^{4} \mathrm{~J}\right.$ $=1.7 \mathrm{~Hz}, 2 \mathrm{H}$, arom), 7.26 (dd, ${ }^{3} \mathrm{~J}=7.4 \mathrm{~Hz},{ }^{4} \mathrm{~J}=1.8 \mathrm{~Hz}, 2 \mathrm{H}$, arom), $7.04\left(\mathrm{dd},{ }^{3} \mathrm{~J}=7.4 \mathrm{~Hz},{ }^{3} \mathrm{~J}=7.4 \mathrm{~Hz}, 2 \mathrm{H}\right.$, arom), $5.29(\mathrm{~s}$, $2 \mathrm{H}, \mathrm{OH}), 0.34\left(\mathrm{~s}, 18 \mathrm{H}, \mathrm{Si}\left(\mathrm{CH}_{3}\right)_{3}\right) .{ }^{13} \mathrm{C} \mathrm{NMR}\left(\mathrm{CDCl}_{3}\right): \delta 158.6$ (C, arom), 136.7 (CH, arom), $132.8(\mathrm{CH}$, arom $), 127.5$ (C, arom), 121.9 (C, arom), 121.7 (C, arom), $-0.3\left(\mathrm{CH}_{3}, \mathrm{Si}\left(\mathrm{CH}_{3}\right)_{3}\right)$. MS: $\mathrm{m} / \mathrm{z}=330\left(\mathrm{M}^{+}\right)$. Mp: $94.0-95.0^{\circ} \mathrm{C}$. Anal. Calcd for $\mathrm{C}_{18} \mathrm{H}_{26} \mathrm{O}_{2^{-}}$ $\mathrm{Si}_{2}$ : $\mathrm{C}, 65.40 ; \mathrm{H}, 7.93$. Found: $\mathrm{C}, 65.72 ; \mathrm{H}, 8.10$.

3,3'-Bis(triethylsilyl)-2,2'-bisphenol (1b). To a solution of 3,3'-dibromo-2,2'-bisphenol $(4.5 \mathrm{mmol}, 1.55 \mathrm{~g}$ ) in DMF (30 $\mathrm{mL}$ ) and imi dazole ( $13.5 \mathrm{mmol}, 0.92 \mathrm{~g}$ ) was added triethylsilyl chloride $(11.3 \mathrm{mmol}, 1.89 \mathrm{~mL})$. The reaction mixture was stirred over night and worked up following a standard literature procedure. ${ }^{17 a}$ The crude triethylsilyl ether was purified by column chromatography (hexane/ $\mathrm{CH}_{2} \mathrm{Cl}_{2}=2 / 1$ (v) v), $\left.R_{f}=0.90\right)$. Yield: $68 \%(3.1 \mathrm{mmol}, 1.77 \mathrm{~g})$ of a white solid. $\mathrm{Mp:} 56.5-58.0{ }^{\circ} \mathrm{C} .{ }^{13} \mathrm{C} \mathrm{NMR}\left(\mathrm{CDCl}_{3}\right): \delta 152.2$ (C arom), 133.3 (CH arom), 131.1 (CH arom), 122.6 (C arom), 122.5 (CH arom), 117.0 ( $\mathrm{C}$ arom), $7.2\left(\mathrm{CH}_{2} \mathrm{CH}_{3}\right), 5.8\left(\mathrm{CH}_{2} \mathrm{CH}_{3}\right)$. ${ }^{1 \mathrm{H}} \mathrm{NMR}$ $\left(\mathrm{CDCl}_{3}\right): \delta 7.54\left(\mathrm{dd}, 2 \mathrm{H}\right.$, arom, ${ }^{3} \mathrm{~J}=7.9 \mathrm{~Hz}$, J $\left.=1.6 \mathrm{~Hz}\right), 7.10$ $(\mathrm{dd}, 2 \mathrm{H}$, arom, $3 \mathrm{~J}=7.5 \mathrm{~Hz}, 4 \mathrm{~J}=1.7 \mathrm{~Hz}), 6.87(\mathrm{dd}, 2 \mathrm{H}$, arom, 3 $=7.7 \mathrm{~Hz}, 3 \mathrm{~J}=7.8 \mathrm{~Hz}), 0.79\left(\mathrm{t}, 18 \mathrm{H}, \mathrm{CH}_{3}\right), 0.36(\mathrm{~m}, 12 \mathrm{H}$, $\mathrm{CH}_{2}$ ). MS: $m / z=573\left(\mathrm{M}^{+}\right)$. Anal. Calcd for $\mathrm{C}_{24} \mathrm{H}_{36} \mathrm{Br}_{2} \mathrm{O}_{2} \mathrm{Si}_{2}$ : C, 50.35; $\mathrm{H}, 6.34$. Found: $\mathrm{C}, 50.49 ; \mathrm{H}, 6.35$.

The triethylsilyl ether $(3.1 \mathrm{mmol}, 1.77 \mathrm{~g}$ ) was azeotropically dried with toluene $(3 \times 1 \mathrm{~mL})$ and dissolved in THF $(40 \mathrm{~mL})$. t-BuLi (1.7 M in pentane, $9.3 \mathrm{mmol}, 5.47 \mathrm{~mL}$ ) was added in $10 \mathrm{~min}$ at $0{ }^{\circ} \mathrm{C}$. The reaction mixture was additionally stirred for $1 \mathrm{~h}$ at room temperature and worked up following a literature procedure. ${ }^{17 a}$ Yield: $66 \%(2.05 \mathrm{mmol}, 2.05 \mathrm{~g})$ of a white solid. ${ }^{13} \mathrm{C} \mathrm{NMR}\left(\mathrm{CDCl}_{3}\right): \delta 158.8(\mathrm{C}$ arom $), 137.5(\mathrm{CH}$ arom), 132.5 ( $\mathrm{CH}$ arom), 124.5 (C arom), 121.8 (C arom), 121.5 (CH arom), $8.2\left(\mathrm{CH}_{2} \mathrm{CH}_{3}\right), 4.0\left(\mathrm{CH}_{2} \mathrm{CH}_{3}\right)$. ${ }^{1} \mathrm{H} \mathrm{NMR}\left(\mathrm{CDCl}_{3}\right): \delta$ $7.43(\mathrm{dd}, 2 \mathrm{H}$, arom, $3 \mathrm{~J}=7.3 \mathrm{~Hz}, 4 \mathrm{~J}=1.7 \mathrm{~Hz}), 7.25(\mathrm{dd}, 2 \mathrm{H}$, arom, 3j $=7.5 \mathrm{~Hz}, 4 \mathrm{~J}=1.7 \mathrm{~Hz}), 7.03(\mathrm{dd}, 2 \mathrm{H}$, arom, 3J $=7.4$ $\left.\mathrm{Hz},{ }^{3} \mathrm{~J}=7.4 \mathrm{~Hz}\right), 5.25(\mathrm{~s}, 2 \mathrm{H}, \mathrm{OH}), 0.97\left(\mathrm{~m}, 18 \mathrm{H}, \mathrm{CH}_{3}\right), 0.90$ $\left(\mathrm{m}, 12 \mathrm{H}, \mathrm{CH}_{2}\right)$. MS: $\mathrm{m} / \mathrm{z}=414\left(\mathrm{M}^{+}\right)$. Anal. Calcd for $\mathrm{C}_{24} \mathrm{H}_{38} \mathrm{O}_{2} \mathrm{Si}_{2}: \mathrm{C}, 69.50 ; \mathrm{H}, 9.24$. Found: $\mathrm{C}, 69.60 ; \mathrm{H}, 9.08 . \mathrm{Mp}$ : $51.5-53.0^{\circ} \mathrm{C}$.

3,3-Bis(tert-butyldimethylsilyl)-2,2'-bisphenol (1c). This compound was prepared as described for $\mathbf{1 b}$. The crude tertbutyldimethylsilyl ether was purified by column chromatography (hexanes $\left./ \mathrm{CH}_{2} \mathrm{Cl}_{2}=2 / 1(\mathrm{v} / \mathrm{v}), \mathrm{R}_{\mathrm{f}}=0.90\right)$. Yield: $96 \%$ (4.82 $\mathrm{mmol}, 2.76 \mathrm{~g})$ of a white powder. $\mathrm{Mp}: 102-103^{\circ} \mathrm{C} .{ }^{13} \mathrm{C} \mathrm{NMR}$ $\left(\mathrm{CDCl}_{3}\right)$ : $\delta 150.3$ (C arom), 132.9 (CH arom), 132.5 (C arom), 131.2 ( $\mathrm{CH}$ arom), 122.0 ( $\mathrm{CH}$ arom), 116.3 (C arom), 25.7 $\left(\mathrm{C}\left(\mathrm{CH}_{3}\right)_{3}\right), 18.3\left(\mathrm{C}_{3}\left(\mathrm{CH}_{3}\right)_{3}\right),-3.5\left(\mathrm{SiCH}_{3}\right),-4.4\left(\mathrm{SiCH}_{3}\right)$. ${ }^{1} \mathrm{H} \mathrm{NMR}$ $\left(\mathrm{CDCl}_{3}\right): \delta 7.52\left(\mathrm{dd}, 2 \mathrm{H}\right.$, arom, $\left.{ }^{3} \mathrm{~J}=8.5 \mathrm{~Hz},{ }^{4} \mathrm{~J}=1.6 \mathrm{~Hz}\right), 7.23$ (dd, $2 \mathrm{H}$, arom, $3 \mathrm{~J}=7.5 \mathrm{~Hz}, 4 \mathrm{~J}=1.5 \mathrm{~Hz}), 6.88$ (dd, $2 \mathrm{H}$, arom, 3) $=7.8 \mathrm{~Hz}, 3 \mathrm{~s}=7.8 \mathrm{~Hz}), 0.92(\mathrm{~s}, 18 \mathrm{H}, \mathrm{t}-\mathrm{Bu}),-0.03(\mathrm{~s}, 6 \mathrm{H}$, $\left.\mathrm{CH}_{3}\right),-0.49\left(\mathrm{~s}, 6 \mathrm{H}, \mathrm{CH}_{3}\right)$. HRMS $(\mathrm{FAB}+) \mathrm{m} / \mathrm{z}=571.0691$ (calcd 573.0680). Anal. Calcd for $\mathrm{C}_{24} \mathrm{H}_{36} \mathrm{Br}_{2} \mathrm{O}_{2} \mathrm{Si}_{2}$ : C, 50.35; $\mathrm{H}, 6.34$. Found: $\mathrm{C}, 50.72 ; \mathrm{H}, 6.42$.

Data for 1c. Compound 1c was purified by column chromatography (EtOAc/PE $\left.60-80^{\circ} \mathrm{C}=2 / 1(\mathrm{v} / \mathrm{v}), \mathrm{R}_{\mathrm{f}}=0.79\right)$. Yield: $90 \%(4.31 \mathrm{mmol}, 1.78 \mathrm{~g})$ of a white solid. Mp: $61.0-62.5^{\circ} \mathrm{C}$.

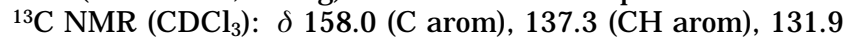
(CH arom), 124.1 (C arom), 121.4 (C arom), 120.6 (CH arom), $26.9\left(\mathrm{C}\left(\mathrm{CH}_{3}\right)_{3}\right), 17.5\left(\mathrm{C}_{3}\left(\mathrm{CH}_{3}\right)_{3}\right),-4.8\left(\mathrm{SiCH}_{3}\right)$. ${ }^{1} \mathrm{H} \mathrm{NMR}$ $\left(\mathrm{CDCl}_{3}\right): \delta 7.44\left(\mathrm{dd}, 2 \mathrm{H}\right.$, arom, $\left.{ }^{3} \mathrm{~J}=7.3 \mathrm{~Hz},{ }^{4} \mathrm{j}=1.6 \mathrm{~Hz}\right), 7.24$ (dd, $2 \mathrm{H}$, arom, $3 \mathrm{~J}=7.4 \mathrm{~Hz}, 4 \mathrm{~J}=1.6 \mathrm{~Hz}), 7.02(\mathrm{dd}, 2 \mathrm{H}$, arom, 3) $=7.4 \mathrm{~Hz}$, 3j $=7.4 \mathrm{~Hz}), 5.26(\mathrm{~s}, 2 \mathrm{H}, \mathrm{OH}), 0.92(\mathrm{~s}, 18 \mathrm{H}$, tert$\mathrm{Bu}), 0.34\left(\mathrm{~s}, 12 \mathrm{H}, \mathrm{CH}_{3}\right) . \mathrm{MS}: \mathrm{m} / \mathrm{z}=427(\mathrm{M}+\mathrm{H})^{+}$. Anal. Calcd for $\mathrm{C}_{24} \mathrm{H}_{38} \mathrm{O}_{2} \mathrm{Si}_{2}$ : C, 69.50; $\mathrm{H}, 9.24$. Found: $\mathrm{C}, 69.38 ; \mathrm{H}, 9.01$.

3,3-Bis(triphenylsilyl)-2,2'-bisphenol (1d). This compound was prepared as described for $\mathbf{1 b}$. The crude triphenylsilyl ether was purified by column chromatography (hexanes $\left./ \mathrm{CH}_{2} \mathrm{Cl}_{2}=2 / 1(\mathrm{v} / \mathrm{v}), \mathrm{R}_{\mathrm{f}}=0.86\right)$. Yield: $76 \%(4.41 \mathrm{mmol}$, $3.79 \mathrm{~g})$ of a white powder. $\mathrm{Mp}$ : $167.7-168.9{ }^{\circ} \mathrm{C}$. ${ }^{1} \mathrm{H} \mathrm{NMR}$ (acetone- $\mathrm{d}_{6}$ ): $\delta 7.62\left(\mathrm{dd}, 2 \mathrm{H}\right.$, arom, $\left.{ }^{3} \mathrm{~J}=8.1 \mathrm{~Hz},{ }^{4} \mathrm{~J}=1.5 \mathrm{~Hz}\right)$, $7.58-7.73(\mathrm{~m}, 28 \mathrm{H}$, arom), $7.25(\mathrm{dd}, 2 \mathrm{H}$, arom, 3j $=9.3 \mathrm{~Hz}, 4 \mathrm{~J}$ $=2.0 \mathrm{~Hz}), 6.66-6.56(\mathrm{~m}, 4 \mathrm{H}$, arom $) .{ }^{13} \mathrm{C} \mathrm{NMR}\left(\mathrm{CDCl}_{3}\right): \delta$
151.0 (C, arom), 136.2 (CH, arom), 134.5 (C, arom), 133.8 (CH, arom), 133.3 (C, arom), $131.1(\mathrm{CH}$, arom $), 130.4(\mathrm{CH}$, arom), 128.1 ( $\mathrm{CH}$, arom), 123.2 ( $\mathrm{CH}$, arom), 117.0 (C, arom). MS: m/z $=860\left(\mathrm{M}^{+}\right)$. Anal. Calcd for $\mathrm{C}_{48} \mathrm{H}_{36} \mathrm{Br}_{2} \mathrm{O}_{2} \mathrm{Si}_{2}: \mathrm{C}, 66.97 ; \mathrm{H}, 4.21$. Found: C, 67.25; $\mathrm{H}, 4.01$.

Data for $\mathbf{1 d}$. Compound $\mathbf{1 d}$ was purified by column chromatography (hexanes/ $\mathrm{CH}_{2} \mathrm{Cl}_{2}=1 / 1(\mathrm{v} / \mathrm{v}), \mathrm{R}_{\mathrm{f}}=0.42$ ). Yield: 98\% (1.96 mmol, $1.38 \mathrm{~g})$ of a white powder. Mp: 167.5-169.0 ${ }^{\circ} \mathrm{C}$. ${ }^{1 \mathrm{H}} \mathrm{NMR}$ (acetone- $\mathrm{d}_{6}$ ): $\delta 7.73\left(\mathrm{dd}, 12 \mathrm{H}\right.$, arom, ${ }^{3} \mathrm{~J}=7.9$ $\mathrm{Hz}, 4 \mathrm{~J}=1.5 \mathrm{~Hz}$ ), 7.62 (dd, $2 \mathrm{H}$, arom, 3 $=7.7 \mathrm{~Hz},{ }^{4} \mathrm{~J}=1.4$ $\mathrm{Hz}), 7.56-7.43\left(\mathrm{~m}, 18 \mathrm{H}\right.$, arom), 7.25 (dd, 2H, arom, ${ }^{3} \mathrm{~J}=7.3$ $\mathrm{Hz}, 4 \mathrm{~J}=1.7 \mathrm{~Hz}$ ), $7.10(\mathrm{dd}, 2 \mathrm{H}$, arom, 3j $=7.4 \mathrm{~Hz}, 3 \mathrm{j}=7.4$ $\mathrm{Hz}), 2.96(\mathrm{~s}, 2 \mathrm{H}, \mathrm{OH}) .{ }^{13} \mathrm{C} \mathrm{NMR}\left(\mathrm{CDCl}_{3}\right): \delta 158.7$ (C, arom), $139.4(\mathrm{CH}$, arom), $137.0(\mathrm{CH}$, arom), $134.9(\mathrm{CH}$, arom), 134.7 (C, arom), 130.4 ( $\mathrm{CH}$, arom), 128.7 (CH, arom), 125.1 (C, arom), $122.1\left(\mathrm{CH}\right.$, arom), $121.6\left(\mathrm{C}\right.$, arom). $\mathrm{MS}: \mathrm{m} / \mathrm{z}=725(\mathrm{M}+\mathrm{Na})^{+}$. Anal. Calcd for $\mathrm{C}_{48} \mathrm{H}_{38} \mathrm{O}_{2} \mathrm{Si}_{2}: \mathrm{C}, 82.01 ; \mathrm{H}, 5.45$. Found: $\mathrm{C}$, 81.55; H, 5.74 .

Compound 3a. 3,3'-Bis(trimethylsilyl)-2,2'-bisphenol (1a) $(1.25 \mathrm{mmol}, 0.41 \mathrm{~g})$ was azeotropically dried with toluene (3 $\times 1 \mathrm{~mL})$, dissolved in toluene $(10 \mathrm{~mL})$, and added slowly to a solution of $\mathrm{PCl}_{3}(2.00 \mathrm{mmol}, 175 \mu \mathrm{L})$ and $\mathrm{Et}_{3} \mathrm{~N}(5.0 \mathrm{mmol}, 0.52$ $\mathrm{mL})$ in toluene $(10 \mathrm{~mL})$ at $0{ }^{\circ} \mathrm{C}$. Subsequently the reaction mixture was stirred $4 \mathrm{~h}$ at room temperature. The formed amine salts were removed by filtration. Evaporation to dryness gave the crude phosphorochloridite, which was used without further purification and was dissolved in toluene (10 $\mathrm{mL})$ and $\mathrm{Et}_{3} \mathrm{~N}(5.0 \mathrm{mmol}, 0.52 \mathrm{~mL})$. To this solution was added (2R,4R)-pentane-2,4-diol $(0.57 \mathrm{mmol}, 59 \mathrm{mg}$, azeotropically dried with $3 \times 1 \mathrm{~mL}$ toluene) in toluene (10 mL) at room temperature. The reaction mixture was stirred overnight, filtrated, and evaporated to dryness. The product was purified by column chromatography (10\% EtOAc/PE $60-80{ }^{\circ} \mathrm{C}(\mathrm{v} / \mathrm{v})$, $\left.\mathrm{R}_{\mathrm{f}}=0.63\right)$. Yield: $81 \%(0.46 \mathrm{mmol}, 0.38 \mathrm{~g})$ of a white solid. Mp: $56-57^{\circ} \mathrm{C} .[\alpha]^{20} \mathrm{D}=30^{\circ}\left(\mathrm{C}=0.10, \mathrm{CH}_{2} \mathrm{Cl}_{2}\right)$. Anal. Calcd for $\mathrm{C}_{41} \mathrm{H}_{58} \mathrm{O}_{6} \mathrm{P}_{2} \mathrm{Si}_{4}$ : C, 59.96; $\mathrm{H}, 7.12$. Found: $\mathrm{C}, 59.50 ; \mathrm{H}, 7.17$. ${ }^{31} \mathrm{P}-{ }^{1} \mathrm{H} N M R$ (benzene- $\left.\mathrm{d}_{6}\right): \delta 145.1\left(\mathrm{~m},{ }^{3} \mathrm{PH}_{\mathrm{PH}}=5.5 \mathrm{~Hz}\right.$, J $\mathrm{pP}=$ $5.2 \mathrm{~Hz}$ ). ${ }^{13} \mathrm{C}$ NMR (benzene- $\left.\mathrm{d}_{6}\right): \delta 154.6\left(\mathrm{t}, \mathrm{C}\right.$ arom, ${ }^{3} \mathrm{~J} \mathrm{PC}=$ $6.8 \mathrm{~Hz}), 154.4(\mathrm{t}, \mathrm{C}$ arom, 3 $\mathrm{PC}=5.4 \mathrm{~Hz}), 135.0(\mathrm{CH}$ arom), 134.9 (CH arom), 132.2 ( $\mathrm{CH}$ arom), 132.1 (CH arom), 131.7 (C arom), 131.6 (C arom), 131.3 (t, $\mathrm{C}$ arom, 3J PC $<2.0 \mathrm{~Hz}), 131.2$ (t, $\mathrm{C}$ arom, 3) PC $<2.0 \mathrm{~Hz}), 124.5$ (CH arom), $124.4(\mathrm{CH}$ arom), $69.6(\mathrm{CH}), 46.4\left(\mathrm{~b}, \mathrm{CH}_{2}\right), 22.1\left(\mathrm{CH}_{3}\right), 0.2\left(\mathrm{Si}\left(\mathrm{CH}_{3}\right)_{3}\right) .{ }^{1} \mathrm{H} \mathrm{NMR}$ (benzene- $\left.\mathrm{d}_{6}\right): \delta$ 7.40-7.38 (m, 4H, arom), 7.19-7.16 (m, 4H, arom), 7.03-6.97 (m, 4H, arom), $4.45(\mathrm{~m}, 2 \mathrm{H}, \mathrm{CH}), 1.92(\mathrm{t}, 2 \mathrm{H}$, $\mathrm{CH}_{2},{ }^{3} \mathrm{~J}=6.5 \mathrm{~Hz}$ ), $1.03\left(\mathrm{~d}, 6 \mathrm{H}, \mathrm{CH}_{3}, 3 \mathrm{~J}=6.1 \mathrm{~Hz}\right), 0.41(\mathrm{~s}, 18$ $\mathrm{H}$, Si $\left.\left(\mathrm{CH}_{3}\right)_{3}\right), 0.39\left(\mathrm{~s}, 18 \mathrm{H}, \mathrm{Si}\left(\mathrm{CH}_{3}\right)_{3}\right)$.

Compound $3 \mathbf{b}$. This compound was prepared as described for 3a. The product was purified by column chromatography $\left(2.0 \% \mathrm{EtOAc} / 5 \% \mathrm{Et}_{3} \mathrm{~N} / \mathrm{PE} 60-80^{\circ} \mathrm{C}(\mathrm{v} / \mathrm{v} / \mathrm{v}), \mathrm{R}_{\mathrm{f}}=0.82\right)$ to yield $73 \%(0.73 \mathrm{mmol}, 0.72 \mathrm{~g})$ of a colorless oil, which was stored as a stock solution in benzene at $-20^{\circ} \mathrm{C} .[\alpha]^{20} \mathrm{D}=70.7^{\circ}(\mathrm{C}=2.47$, $\mathrm{C}_{6} \mathrm{H}_{6}$ ). Anal. Calcd for $\mathrm{C}_{53} \mathrm{H}_{82} \mathrm{O}_{6} \mathrm{P}_{2} \mathrm{Si}_{4}: \mathrm{C}, 64.46 ; \mathrm{H}, 8.17$. Found: $\mathrm{C}, 64.50 ; \mathrm{H}, 8.47$. ${ }^{31} \mathrm{P}-{ }^{1} \mathrm{H}$ NMR $\left(\mathrm{CDCl}_{3}\right): \delta 147.1(\mathrm{~m}$, $\left.{ }^{3} \mathrm{PH}_{\mathrm{PH}}=7.0, \mathrm{~J} \mathrm{PP}=9.0 \mathrm{~Hz}\right) .{ }^{13} \mathrm{C} \mathrm{NMR}\left(\mathrm{CDCl}_{3}\right): \delta 155.2(\mathrm{t}, \mathrm{C}$ arom), 154.8 (t, $\mathrm{C}$ arom), 136.5 (CH arom), 136.4 (CH arom), 132.69 (CH arom), 132.67 (CH arom), 132.0 (t, C arom), 131.7 (t, $\mathrm{C}$ arom), 129.6 (C arom), 129.5 (C arom), 124.9 (CH arom), $124.7\left(\mathrm{CH}\right.$ arom), $70.1(\mathrm{t}, \mathrm{CH}), 47.2\left(\mathrm{CH}_{2}\right), 23.1\left(\mathrm{CH}_{3}\right), 8.1$ $\left(\mathrm{CH}_{2} \mathrm{CH}_{3}\right), 4.5\left(\mathrm{CH}_{2} \mathrm{CH}_{3}\right)$. ${ }^{1} \mathrm{H} N M R\left(\mathrm{CDCl}_{3}\right): \delta 7.42(\mathrm{dd}, 4 \mathrm{H}$, arom, $\left.{ }^{3} \mathrm{~J}=7.3 \mathrm{~Hz},{ }^{4} \mathrm{~J}=1.0 \mathrm{~Hz}\right), 7.38\left(\mathrm{dd}, 4 \mathrm{H}\right.$, arom, ${ }^{3} \mathrm{~J}=7.6$ $\mathrm{Hz}, 4 \mathrm{~J}=1.0 \mathrm{~Hz}$ ), $7.38\left(\mathrm{dd}, 2 \mathrm{H}\right.$, arom, 3 $=7.4 \mathrm{~Hz}, 3^{3}=7.4$ $\mathrm{Hz}), 7.23(\mathrm{dd}, 2 \mathrm{H}$, arom, 3j $=7.4 \mathrm{~Hz}, 3 \mathrm{j}=7.4 \mathrm{~Hz}), 4.39(\mathrm{~m}$, $2 \mathrm{H}, \mathrm{CH}), 1.84\left(\mathrm{t}, 2 \mathrm{H}, \mathrm{CH}_{2},{ }^{3} \mathrm{~J}=6.4 \mathrm{~Hz}\right), 1.11\left(\mathrm{~d}, 6 \mathrm{H}, \mathrm{CH}_{3},{ }^{3} \mathrm{~J}\right.$ $=6.2 \mathrm{~Hz}), 0.93\left(\mathrm{~m}, 60 \mathrm{H}, \mathrm{CH}_{2} \mathrm{CH}_{3}\right)$.

Compound $3 \mathrm{c}$. This compound was prepared as described for 3a.The product was purified by column chromatography (2.5\% EtOAc/5\% Et $\left.{ }_{3} \mathrm{~N} / \mathrm{PE} 60-80{ }^{\circ} \mathrm{C}(\mathrm{v} / \mathrm{v} / \mathrm{v}), \mathrm{R}_{\mathrm{f}}=0.74\right)$. Yield: $81 \%(0.81 \mathrm{mmol}, 0.80 \mathrm{~g})$ of a white solid. $\mathrm{Mp}: 65-67^{\circ} \mathrm{C} .[\alpha]^{20} \mathrm{D}$ $=-27.0^{\circ}\left(\mathrm{c}=0.10, \mathrm{CH}_{2} \mathrm{Cl}_{2}\right)$. ${ }^{31} \mathrm{P}-{ }^{1} \mathrm{H} \mathrm{NMR}\left(\mathrm{CDCl}_{3}\right): \delta 139.4$ $\left(\mathrm{d},{ }^{3} \mathrm{PH}_{\mathrm{PH}}=8.5 \mathrm{~Hz}\right) .{ }^{13} \mathrm{C} \mathrm{NMR}$ (benzene- $\left.\mathrm{d}_{6}\right): \delta 154.9(\mathrm{~m}, \mathrm{C}$ arom), 136.4 (CH arom), 136.3 (CH arom), 132.3 (CH arom), 132.1 (CH arom), 131.6 (m, C arom), 128.9 (C arom), 128.8 (C arom), 
124.0 ( $\mathrm{CH}$ arom), 123.9 ( $\mathrm{CH}$ arom), 69.4 (d, $\mathrm{CH},{ }^{2} \mathrm{JPC}=5.2$

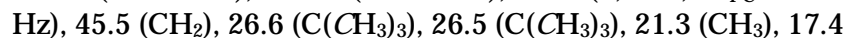
$\left(\mathrm{C}\left(\mathrm{CH}_{3}\right)_{3}\right), 17.3\left(\mathrm{C}\left(\mathrm{CH}_{3}\right)_{3}\right),-3.5\left(\mathrm{Si}\left(\mathrm{CH}_{3}\right)_{3}\right),-3.7\left(\mathrm{Si}\left(\mathrm{CH}_{3}\right)_{3}\right) .{ }^{1} \mathrm{H}$ NMR $\left(\mathrm{CDCl}_{3}\right): \delta 7.46(\mathrm{dd}, 2 \mathrm{H}$, arom, $3 \mathrm{j}=7.3 \mathrm{~Hz}, 4 \mathrm{~J}=1.7$ $\mathrm{Hz}$ ), 7.42 (dd, $2 \mathrm{H}$, arom, 3J $=7.3 \mathrm{~Hz},{ }^{4} \mathrm{~J}=1.7 \mathrm{~Hz}$ ), 7.35 (dd, $2 \mathrm{H}$, arom, $3 \mathrm{~J}=5.0 \mathrm{~Hz}$, 4 $=1.7 \mathrm{~Hz}), 7.33(\mathrm{dd}, 2 \mathrm{H}$, arom, $3 \mathrm{~J}=$ $\left.5.1 \mathrm{~Hz},{ }^{4} \mathrm{~J}=1.7 \mathrm{~Hz}\right), 7.21\left(\mathrm{dd}, 2 \mathrm{H}\right.$, arom, ${ }^{3} \mathrm{~J}=7.5 \mathrm{~Hz},{ }^{3} \mathrm{~J}=7.4$ $\mathrm{Hz}), 7.18\left(\mathrm{dd}, 2 \mathrm{H}\right.$, arom, $\left.{ }^{3} \mathrm{~J}=7.5 \mathrm{~Hz},{ }^{3} \mathrm{~J}=7.4 \mathrm{~Hz}\right), 3.96(\mathrm{~m}$, $2 \mathrm{H}, \mathrm{CH}), 1.69\left(\mathrm{t}, 2 \mathrm{H}, \mathrm{CH}_{2}, 3 \mathrm{~J}=7.1 \mathrm{~Hz}\right), 0.84\left(\mathrm{~s}, 18 \mathrm{H}, \mathrm{C}\left(\mathrm{CH}_{3}\right)_{3}\right)$, $0.83\left(\mathrm{~s}, 18 \mathrm{H}, \mathrm{C}\left(\mathrm{CH}_{3}\right)_{3}\right), 0.66\left(\mathrm{~d}, 6 \mathrm{H}, \mathrm{CH}_{3}, 3 \mathrm{~J}=6.1 \mathrm{~Hz}\right), 0.45(\mathrm{~s}$, $\left.6 \mathrm{H}, \mathrm{CH}_{3}\right), 0.40\left(\mathrm{~s}, 6 \mathrm{H}, \mathrm{CH}_{3}\right), 0.39\left(\mathrm{~s}, 6 \mathrm{H}, \mathrm{CH}_{3}\right), 0.36(\mathrm{~s}, 6 \mathrm{H}$, $\left.\mathrm{CH}_{3}\right)$. MS: $\mathrm{m} / \mathrm{z}=1012(\mathrm{M}+\mathrm{Na})^{+}$. Anal. Calcd for $\mathrm{C}_{53} \mathrm{H}_{82} \mathrm{O}_{6} \mathrm{P}_{2^{-}}$ $\mathrm{Si}_{4}$ : C, 64.33; H, 8.36. Found: C, 64.77; H, 8.57.

Racemic (R/S)-( \pm )-2,2'-bis(1-ethoxyethoxy)-1,1'-binaphthyl. This compound was prepared in situ according to a literature procedure. ${ }^{19}$ Racemic (R/S)-( $( \pm)-2,2^{\prime}$-bisnaphthol (15.0 mmol, $4.30 \mathrm{~g})$ was azeotropically dried with toluene (3 $\times 5 \mathrm{~mL})$ and dissolved in a solution of pyridinium p-toluenesulfonate $(1.5 \mathrm{mmol}, 0.40 \mathrm{~g})$ in $\mathrm{CH}_{2} \mathrm{Cl}_{2}(125 \mathrm{~mL})$. Ethyl vinyl ether $(45.0 \mathrm{mmol}, 4.30 \mathrm{~mL})$ was slowly added at room temperature and the mixtured stirred for $72 \mathrm{~h}$. The reaction mixture was poured into water and extracted with diethyl ether. The organic phase was washed with brine and dried on $\mathrm{MgSO}_{4}$. Evaporation of the solvent gave (R/S)-( $( \pm)-2,2^{\prime}$-bis(1-ethoxyethoxy)-1,1'-binaphthyl in quantitative yield. A complex ${ }^{1} \mathrm{H}$ NMR spectrum was obtained for the diastereomeric mixture. The product was used in the subsequent reactions without further purification.

(R)-(+)- and (S)-(-)-2,2'-Bis(1-ethoxyethoxy)-1,1'-binaphthyl. These compounds were prepared according to the procedure as described for racemic (R/S)-( \pm )-2,2'-bis(1-ethoxyethoxy)-1,1'-binaphthyl in a quantitative yield. Data for the (S)-enantiomer: Yellow oil. ${ }^{1} \mathrm{H} \mathrm{NMR}\left(\mathrm{CDCl}_{3}\right): \delta 7.92\left(\mathrm{~d},{ }^{3} \mathrm{j}=\right.$ $9.0 \mathrm{~Hz}, 2 \mathrm{H}$, arom), 7.67 (d, 3j = $8.2 \mathrm{~Hz}, 2 \mathrm{H}$, arom), 7.58 (dd, 3 $=8.9 \mathrm{~Hz},{ }^{4} \mathrm{~J}=2.2 \mathrm{~Hz}, 1 \mathrm{H}$, arom), $7.57\left(\mathrm{~d},{ }^{3} \mathrm{~J}=9.0 \mathrm{~Hz}, 1 \mathrm{H}\right.$, arom), 7.35 (dd, 3j $=7.1 \mathrm{~Hz}, 3 \mathrm{~J}=7.1 \mathrm{~Hz}), 7.17(\mathrm{~m}, 4 \mathrm{H}$, arom), $5.20(\mathrm{~m}, 1 \mathrm{H}), 5.09(\mathrm{~m}, 1 \mathrm{H}), 3.45(\mathrm{~m}, 2 \mathrm{H}), 3.27(\mathrm{~m}, 1 \mathrm{H}), 3.16$ $(\mathrm{m}, 1 \mathrm{H}), 1.19(\mathrm{~m}, 3 \mathrm{H}), 1.06(\mathrm{~m}, 6 \mathrm{H}), 0.97(\mathrm{~m}, 3 \mathrm{H})$. The (R)enantiomer gave identical chemical shifts. The product was used in the subsequent reactions without further purification.

Racemic (R/S)-( \pm )-3,3'-Bis(trimethylsilyl)-2,2' -bis(1ethoxyethoxy)-1,1'-binaphthyl. This compound was prepared according to the procedure described for 3,3'-bis(trimethylsilyl)-2,2'-bis(1-ethoxyethoxy)-1,1'-biphenyl. Yield: $71 \%$ (2.87 mmol, $1.65 \mathrm{~g}$ ). A complex ${ }^{1} \mathrm{H}$ NMR spectrum was obtained for the diastereomeric mixture. The product was used in the subsequent reactions without further purification.

(R)-(+)- and (S)-(-)-3,3'-Bis(trimethylsilyl)-2,2'-bis(1ethoxyethoxy)-1,1'-binaphthyl. These compounds were prepared according to the procedure as described for 3,3'-bis(trimethylsilyl)-2,2'-bis(1-ethoxyethoxy)-1,1'-bi phenyl. Data for the (S)-enantiomer: Yield: $88 \%(1.75 \mathrm{mmol}, 1.01 \mathrm{~g}) .{ }^{1} \mathrm{H}$ NMR $\left(\mathrm{CDCl}_{3}\right): \delta 8.06(\mathrm{~d}, 4 \mathrm{~J}=2.9 \mathrm{~Hz}, 2 \mathrm{H}, \operatorname{arom}), 7.89$ (dd, 3) $=7.3 \mathrm{~Hz},{ }^{3} \mathrm{~J}=7.3 \mathrm{~Hz}, 2 \mathrm{H}$, arom), $7.37(\mathrm{~m}, 2 \mathrm{H}$, arom), $7.28(\mathrm{~m}$, $4 \mathrm{H}$, arom), $4.33(\mathrm{~m}, 1 \mathrm{H}), 4.07(\mathrm{~m}, 1 \mathrm{H}), 3.80(\mathrm{~m}, 1 \mathrm{H}), 3.10(\mathrm{~m}$, $1 \mathrm{H}), 2.97(\mathrm{~m}, 1 \mathrm{H}), 2.68(\mathrm{~m}, 1 \mathrm{H}), 1.07\left(\mathrm{~m}, 3 \mathrm{H}, \mathrm{CH}_{3}\right), 0.94(\mathrm{~m}$, $\left.3 \mathrm{H}, \mathrm{CH}_{3}\right), 0.74\left(\mathrm{~m}, 6 \mathrm{H}, \mathrm{CH}_{3}\right), 0.42\left(\mathrm{~m}, 18 \mathrm{H}, \mathrm{Si}\left(\mathrm{CH}_{3}\right)_{3}\right)$.

Racemic (R/S)-( \pm )-3,3-Bis(trimethylsilyl)-2,2 -bisnaphthol ((R/S)-2a). Racemic (R/S)-( \pm )-3,3'-bis(trimethylsilyl)-2,2'bis(1-ethoxyethoxy)-1,1'-binaphthyl (2.87 mmol, $1.65 \mathrm{~g}$ ) was deprotected with pyridinium p-toluene sulfonate according to a literature procedure. ${ }^{19}$ The product was purified by column chromatography $\left(2.5 \%\right.$ EtOAc/PE $\left.60-80^{\circ} \mathrm{C}(\mathrm{v} / \mathrm{v}), \mathrm{R}_{\mathrm{f}}=0.31\right)$. $\mathrm{Mp:} 158-160{ }^{\circ} \mathrm{C}$. Yield: $66 \%(1.93 \mathrm{mmol}, 0.83 \mathrm{~g})$ of a white powder. ${ }^{13} \mathrm{C} \mathrm{NMR}\left(\mathrm{CDCl}_{3}\right): \delta 158.4(\mathrm{C}$ arom), 139.2 (CH arom), 135.7 (C arom), 130.7 (C arom), 130.3 (C arom), $130.0(\mathrm{CH}$ arom), 129.0 ( $\mathrm{CH}$ arom), 125.4 (CH arom), 125.1 ( $\mathrm{CH}$ arom), 111.0 (C arom), $0.57\left(\mathrm{Si}(\mathrm{CH})_{3}\right) .{ }^{1} \mathrm{H} \mathrm{NMR}\left(\mathrm{CDCl}_{3}\right): \delta 8.07(\mathrm{~s}$, $2 \mathrm{H}$, arom), 7.89 (dd, 3j $=8.0 \mathrm{~Hz}, 4 \mathrm{~J}=1.2 \mathrm{~Hz}, 2 \mathrm{H}$, arom), 7.35 (ddd, ${ }^{3} \mathrm{~J}=6.6 \mathrm{~Hz},{ }^{3} \mathrm{~J}=6.6 \mathrm{~Hz},{ }^{4} \mathrm{~J}=1.5 \mathrm{~Hz}, 2 \mathrm{H}$, arom), 7.29 (ddd, 3j $=6.7 \mathrm{~Hz},{ }^{3} \mathrm{~J}=6.7 \mathrm{~Hz}$, य $=1.6 \mathrm{~Hz}, 2 \mathrm{H}$, arom), 7.09 (d,
3) $=8.2 \mathrm{~Hz}, 2 \mathrm{H}$, arom), $4.86(\mathrm{~s}, 2 \mathrm{H}, \mathrm{OH}), 0.41(\mathrm{~s}, 18 \mathrm{H}, \mathrm{Si}-$ $\left.\left(\mathrm{CH}_{3}\right)_{3}\right)\left(\mathrm{lit.}^{34}{ }^{1} \mathrm{H}\right.$ NMR 8.07, 7.89, 7.35, 7.28, 7.09, 5.2, 0.41).

(R)-(+)- and (S)-(-)-3,3'-Bis(trimethylsilyl)-2,2'-bisnaphthol ((R)-2a) and ((S)-2a). These compounds were prepared according to the procedure as described for (R/S)2a. (R)-(-)-3,3'-Bis(trimethylsilyl)-2,2'-bis(1-ethoxyethoxy)$1,1^{\prime}$-binaphthyl $(1.75 \mathrm{mmol}, 1.01 \mathrm{~g})$ was deprotected with pyridinium $\mathrm{p}$-toluenesulfonate according to a literature procedure. ${ }^{19}$ The product was purified by column chromatography (5.0\% EtOAc/PE $\left.60-80{ }^{\circ} \mathrm{C}(\mathrm{v} / \mathrm{v}), \mathrm{R}_{\mathrm{f}}=0.24\right)$. Yield: $97 \%$ (1.69 $\mathrm{mmol}, 0.73 \mathrm{~g})$ of a white powder. ${ }^{1 \mathrm{H} N M R}\left(\mathrm{CDCl}_{3}\right): \delta 8.08(\mathrm{~s}$, $2 \mathrm{H}$, arom), 7.89 (dd, $3 \mathrm{~J}=8.0 \mathrm{~Hz},{ }^{4} \mathrm{~J}=1.1 \mathrm{~Hz}, 2 \mathrm{H}$, arom), 7.36 (ddd, $3 \mathrm{~J}=6.8 \mathrm{~Hz},{ }^{3} \mathrm{~J}=6.8 \mathrm{~Hz},{ }^{4} \mathrm{~J}=1.1 \mathrm{~Hz}, 2 \mathrm{H}$, arom), 7.29 (ddd, 3j $=8.6 \mathrm{~Hz},{ }^{3} \mathrm{~J}=8.6 \mathrm{~Hz}, 4 \mathrm{~J}=1.4 \mathrm{~Hz}, 2 \mathrm{H}$, arom), 7.09 (dd, 3j $=8.2 \mathrm{~Hz}, 4 \mathrm{j}=1.1 \mathrm{~Hz}, 2 \mathrm{H}$, arom), $5.24(\mathrm{~s}, 2 \mathrm{H}, \mathrm{OH})$, $0.41\left(\mathrm{~s}, 18 \mathrm{H}, \mathrm{Si}\left(\mathrm{CH}_{3}\right)_{3}\right) .[\alpha]^{20} \mathrm{D}=+142^{\circ}(\mathrm{c}=0.52, \mathrm{THF})$ [lit. ${ }^{17 \mathrm{a}}$ $[\alpha]^{20}{ }_{D}+143^{\circ}\left(\mathrm{C}=0.985\right.$, THF )]. Mp: $70.5-73{ }^{\circ} \mathrm{C}$ (lit. ${ }^{17 a} \mathrm{mp}$ $\left.68-71^{\circ} \mathrm{C}\right)$. The same route has been followed for the (S)enantiomer.

Racemic (R/S)-( \pm )-3,3'-Dibromo-2,2'-bisnaphthol. This compound was prepared according to a literature procedure. 17a,32 Mp: $158-160^{\circ} \mathrm{C}$. ${ }^{1} \mathrm{H} \mathrm{NMR}\left(\mathrm{CDCl}_{3}\right): \delta 8.26$ (s, $2 \mathrm{H}$, arom), 7.82 (d, $2 \mathrm{H}, \operatorname{arom}^{3}$ J $\left.=8.0 \mathrm{~Hz}\right), 7.39$ (ddd, $2 \mathrm{H}$, arom, 3 $\mathrm{J}=7.9 \mathrm{~Hz}$,

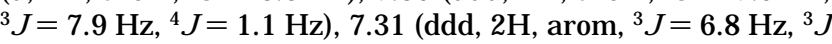
$=6.8 \mathrm{~Hz}, 4 \mathrm{~J}=1.2 \mathrm{~Hz}), 7.10(\mathrm{~d}, 2 \mathrm{H}$, arom, $3 \mathrm{~J}=8.3 \mathrm{~Hz}), 5.55$ $(\mathrm{s}, 2 \mathrm{H}, \mathrm{OH})\left[\mathrm{lit}^{34}{ }^{1} \mathrm{H}\right.$ NMR 8.35, 7.9, 7.40, 7.30, 7.00, $\left.8.45(\mathrm{OH})\right]$. ${ }^{13} \mathrm{C} \mathrm{NMR}\left(\mathrm{CDCl}_{3}\right): \delta 148.7(\mathrm{C}$, arom), $133.5(\mathrm{CH}$, arom), 130.4 (C, arom), $128.3(\mathrm{CH}, \operatorname{arom}), 125.6(\mathrm{CH}, \operatorname{arom}), 125.3(\mathrm{CH}$, arom), 115.3 (C, arom), 112.9 (C, arom).

Racemic (R/S)-( \pm )-3,3'-Bis(triethylsilyl)-2,2'-bisnaphthol ((R/S)-2b). This compound was prepared according to a literature procedure for analogous compounds. ${ }^{17 a}$ Yield: $70 \%$ after purification by column chromatography (10\% EtOAc/PE $\left.60-80{ }^{\circ} \mathrm{C}(\mathrm{v} / \mathrm{v}), \mathrm{R}_{\mathrm{f}}=0.54\right) . \mathrm{Mp}: 134-136{ }^{\circ} \mathrm{C}$. ${ }^{1} \mathrm{H} N M R$ $\left(\mathrm{CDCl}_{3}\right): \delta 8.07(\mathrm{~s}, 2 \mathrm{H}, \operatorname{arom}), 7.89\left(\mathrm{~d}, 2 \mathrm{H}, \operatorname{arom}^{3}{ }^{3}=7.7 \mathrm{~Hz}\right)$, 7.36 (ddd, $2 \mathrm{H}$, arom, 3j $=6.7 \mathrm{~Hz}, 3 \mathrm{~J}=6.7 \mathrm{~Hz}, 4 \mathrm{j}=1.0 \mathrm{~Hz}$ ), 7.29 (ddd, $2 \mathrm{H}$, arom, 3j $=6.8 \mathrm{~Hz}, 3 \mathrm{~J}=6.7 \mathrm{~Hz}, 4 \mathrm{~J}=1.3 \mathrm{~Hz}$ ), $7.09(\mathrm{~d}, 2 \mathrm{H}$, arom, 3) $=8.2 \mathrm{~Hz}), 5.22(\mathrm{~s}, 2 \mathrm{H}, \mathrm{OH}), 1.10-0.87$ $\left(\mathrm{m}, 30 \mathrm{H}, \mathrm{Si}\left(\mathrm{CH}_{2} \mathrm{CH}_{3}\right)_{3}\right) .{ }^{13} \mathrm{C} \mathrm{NMR}\left(\mathrm{CDCl}_{3}\right): \delta 157.8(\mathrm{C}$, arom), 139.8 (CH, arom), 134.9 (C, arom), 130.0 (C, arom), $129.2(\mathrm{CH}$, arom), $128.3(\mathrm{CH}$, arom $), 126.9(\mathrm{C}$, arom $), 124.6(\mathrm{CH}$, arom), $124.3(\mathrm{CH}$, arom $\left.), 110.1(\mathrm{C}, \mathrm{arom}), 8.4\left(\mathrm{CH}_{2}, \mathrm{SiEt}\right)_{3}\right), 4.2\left(\mathrm{CH}_{3}\right.$, SiEt $t_{3}$. Anal. Calcd for $\mathrm{C}_{32} \mathrm{H}_{42} \mathrm{O}_{2} \mathrm{Si}_{2}$ : C, 74.65; $\mathrm{H}, 8.23$. Found: C, 73.86; H, 8.30.

Racemic (R/S)-( \pm )-3,3-Bis(tert-butyldimethylsilyl)-2,2 bisnaphthol ((R/S)-2c). This compound was prepared according to a literature procedure. ${ }^{17 a} \mathrm{Mp}: 217.5-218.5^{\circ} \mathrm{C} .{ }^{1} \mathrm{H}$ NMR $\left(\mathrm{CDCl}_{3}\right): \delta 8.08(\mathrm{~s}, 2 \mathrm{H}$, arom), $7.89(\mathrm{~d}, 2 \mathrm{H}$, arom, $3 \mathrm{~J}=$ $8.0 \mathrm{~Hz}, 4 \mathrm{~J}=1.2 \mathrm{~Hz}$ ), 7.35 (ddd, $2 \mathrm{H}$, arom, $3 \mathrm{~J}=6.8 \mathrm{~Hz}, 3 \mathrm{~J}=$ $6.8 \mathrm{~Hz}, 4 \mathrm{~J}=1.3 \mathrm{~Hz}$ ), $7.29(\mathrm{ddd}, 2 \mathrm{H}$, arom, 3j $=6.7 \mathrm{~Hz}, 3 \mathrm{~J}=$ $6.6 \mathrm{~Hz}, 4 \mathrm{~J}=1.4 \mathrm{~Hz}), 7.09(\mathrm{~d}, 2 \mathrm{H}$, arom, $3 \mathrm{j}=8.2 \mathrm{~Hz}), 5.22(\mathrm{~s}$, $2 \mathrm{H}, \mathrm{OH}), 0.95\left(\mathrm{~s}, 18 \mathrm{H}\right.$, Sit-Bu) $0.43\left(\mathrm{~s}, 6 \mathrm{H}, \mathrm{SiCH}_{3}\right), 0.42(\mathrm{~s}$, $\left.6 \mathrm{H}, \mathrm{SiCH}_{3}\right) .{ }^{13} \mathrm{C} \mathrm{NMR}\left(\mathrm{CDCl}_{3}\right): \delta 157.8(\mathrm{C}, \operatorname{arom}), 140.1(\mathrm{CH}$, arom), 134.9 (C, arom), 129.8 (C, arom), 129.3 (CH, arom), $128.3(\mathrm{CH}$, arom), 127.4 (C, arom), $124.5(\mathrm{CH}$, arom), 124.3 $(\mathrm{CH}$, arom $), 110.3(\mathrm{C}$, arom $), 27.8(\mathrm{CH} 3$, tert-Butyl $), 18.3\left(\mathrm{CH}_{3}\right.$, $\mathrm{t}-\mathrm{Bu}),-4.4\left(\mathrm{CH}_{3}, \mathrm{Si}\left(\mathrm{CH}_{3}\right)_{2}(\mathrm{t}-\mathrm{Bu})\right),-4.5\left(\mathrm{CH}_{3}, \mathrm{Si}\left(\mathrm{CH}_{3}\right)_{2}(\mathrm{t}-\mathrm{Bu})\right)$. MS: $\mathrm{m} / \mathrm{z}=514\left(\mathrm{M}^{+}\right)$. Anal. Calcd for $\mathrm{C}_{32} \mathrm{H}_{42} \mathrm{O}_{2} \mathrm{Si}_{2}$ : C, 74.65; $H$, 8.23. Found: C, 74.57; $\mathrm{H}, 8.30$.

Compound 4a. Compound (R/S)-2a (1.05 mmol) was azeotropically dried with toluene $(3 \times 1 \mathrm{~mL})$, dissolved in toluene $(10 \mathrm{~mL})$ and added slowly to a solution of $\mathrm{PCl}_{3}(1.32$ $\mathrm{mmol}, 115 \mu \mathrm{L})$ and $\mathrm{Et}_{3} \mathrm{~N}(3.0 \mathrm{mmol}, 0.31 \mathrm{~mL})$ in toluene $(10$ $\mathrm{mL}$ ) at $0{ }^{\circ} \mathrm{C}$. The reaction mixture was stirred overnight at room temperature. The formed amine salts were removed by filtration. Evaporation to dryness gave the crude phosphorochloridite, which was used without further purification and dissolved in toluene $(10 \mathrm{~mL})$ and $\mathrm{Et}_{3} \mathrm{~N}(3.0 \mathrm{mmol}, 0.31 \mathrm{~mL})$. To this solution was added $(2 \mathrm{R}, 4 \mathrm{R})$-pentane-2,4-diol $(0.48$ $\mathrm{mmol}, 50 \mathrm{mg}$, azeotropically dried with toluene $3 \times 1 \mathrm{~mL}$ ) in

(33) Adams, R.; Kornblum, N. J . Am. Chem. Soc. 1941, 63, 188.

(34) Van der Línden, A.; Schaverien, C. J .; Meijboom, N.; Ganter, C.; Orpen, A. G. J . Am. Chem. Soc. 1995, 117, 3008. 
toluene $(10 \mathrm{~mL})$ at room temperature. The reaction mixture was stirred overnight, filtrated, and evaporated to dryness. The diastereomeric mixture was purified by column chromatography $\left(10 \%\right.$ EtOAC/PE $\left.60-80{ }^{\circ} \mathrm{C}(\mathrm{v} / \mathrm{v}), \mathrm{R}_{\mathrm{f}}=0.46\right)$. Yield: $87 \%(0.41 \mathrm{mmol}, 0.42 \mathrm{~g})$ of a white solid. ${ }^{31} \mathrm{P}-{ }^{1} \mathrm{H} N M R$ (benzene- $\left.d_{6}\right): 5=\delta 146.1\left(\mathrm{~m}, \mathrm{~J}\right.$ PP $\left.=13 \mathrm{~Hz},{ }^{3} \mathrm{JPH}_{\mathrm{PH}}=7.2 \mathrm{~Hz}\right), \mathbf{7}$ $=\delta 144.7\left(\mathrm{~d}, 3 \mathrm{~J}_{\mathrm{PH}}=7.3 \mathrm{~Hz}\right), \mathbf{8}=\delta 144.42\left(\mathrm{~d}, 3_{\mathrm{PH}}=8.5 \mathrm{~Hz}\right)$ and $144.24\left(\mathrm{~d}, 3 \mathrm{~J}_{\mathrm{PH}}=7.3 \mathrm{~Hz}\right)$.

Compound $\mathbf{4 b}$. This compound was prepared as described for 3a. The diastereomeric mixture was purified by column chromatography (1\% $\mathrm{Et}_{3} \mathrm{~N} / 15 \% \mathrm{EtOAc} / \mathrm{PE} 60-80{ }^{\circ} \mathrm{C}(\mathrm{v} / \mathrm{v} / \mathrm{v})$, $\left.\mathrm{R}_{\mathrm{f}}=0.72\right)$. Yield: $47 \%(0.22 \mathrm{mmol}, 0.26 \mathrm{~g})$ of a white solid. Mp: $106.5-107.5^{\circ} \mathrm{C}$. ${ }^{31} \mathrm{P}-{ }^{1} \mathrm{H}$ NMR (benzene- $\mathrm{d}_{6}$ ): $\delta 148.2(\mathrm{~b})$, $146.9\left(\mathrm{~d}, 3 \mathrm{JPH}_{\mathrm{PH}}=8.5 \mathrm{~Hz}\right), 145.8\left(\mathrm{~d}, 3 \mathrm{f}_{\mathrm{PH}}=8.5 \mathrm{~Hz}\right), 144.9(\mathrm{~d}$, 3J $\mathrm{PH}=8.5 \mathrm{~Hz})$. MS: $\mathrm{m} / \mathrm{z}=1212(\mathrm{M}+\mathrm{Na})^{+}$. Anal. Calcd for $\mathrm{C}_{69} \mathrm{H}_{90} \mathrm{O}_{6} \mathrm{P}_{2} \mathrm{Si}_{4}:$ C, 69.65; $\mathrm{H}, 7.63$. Found: C, 70.31; $\mathrm{H}, 7.96$.

Compound 4c. This compound was prepared as described for 3a. The diastereomeric mixture was purified by column chromatography $\left(1 \% \mathrm{Et}_{3} \mathrm{~N} / 15 \% \mathrm{EtOAC} / \mathrm{PE} 60-80{ }^{\circ} \mathrm{C}(\mathrm{v} / \mathrm{v} / \mathrm{v})\right.$, $\left.\mathrm{R}_{\mathrm{f}}=0.75\right)$. Yield: $76 \%(0.53 \mathrm{mmol}, 0.80 \mathrm{~g})$ of a white solid. ${ }^{31} \mathrm{P}-{ }^{1} \mathrm{H}$ NMR (benzene- $\mathrm{d}_{6}$ ): $\delta 139.9\left(\mathrm{~d},{ }^{3} \mathrm{PH}_{\mathrm{PH}}=7.3 \mathrm{~Hz}\right.$ ), 138.7 $\left.(d, 3)_{\mathrm{PH}}=9.7 \mathrm{~Hz}\right), 137.9\left(\mathrm{~d}, 3 \mathrm{~J}_{\mathrm{PH}}=8.5 \mathrm{~Hz}\right), 136.8\left(\mathrm{~d}, 3 \mathrm{~J}_{\mathrm{PH}}=\right.$ 9.7 Hz). Anal. Calcd for $\mathrm{C}_{69} \mathrm{H}_{90} \mathrm{O}_{6} \mathrm{P}_{2} \mathrm{Si}_{4}: \mathrm{C}, 69.65 ; \mathrm{H}, 7.63$. Found: C, 70.37; $\mathrm{H}, 8.03$.

Compound 5. This compound was prepared as described for 3a. (S)-(-)-3,3'-Bis(trimethylsilyl)-2,2'-bisnaphthol (1.23 mmol, $0.53 \mathrm{~g}$ ) was used for the synthesis of $\mathbf{5}$. The product was purified by column chromatography (5\% EtOAc/PE 60$\left.80{ }^{\circ} \mathrm{C},(\mathrm{v} / \mathrm{v}), \mathrm{R}_{\mathrm{f}}=0.39\right)$. Yield: $96 \%(0.48 \mathrm{mmol}, 0.50 \mathrm{~g})$ of a white solid. Mp: $124-126{ }^{\circ} \mathrm{C}$. Anal. Calcd for $\mathrm{C}_{57} \mathrm{H}_{66} \mathrm{O}_{6} \mathrm{P}_{2^{-}}$ $\mathrm{Si}_{4}$ : $\mathrm{C}, 67.02 ; \mathrm{H}, 6.51$. Found: $\mathrm{C}, 67.11 ; \mathrm{H}, 6.95$. $[\alpha]^{20}{ }_{\mathrm{D}}=51.6^{\circ}$ $\left(\mathrm{c}=0.10, \mathrm{CH}_{2} \mathrm{Cl}_{2}\right.$ ). ${ }^{31} \mathrm{P} \mathrm{NMR}$ (benzene- $\mathrm{d}_{6}$ ): $\delta 146.1 .{ }^{13} \mathrm{C} \mathrm{NMR}$ (benzene- $\mathrm{d}_{6}$ ): $\delta 152.7(\mathrm{t}, \mathrm{C}$ arom, J PC $=6.0 \mathrm{~Hz}), 152.1(\mathrm{t}, \mathrm{C}$ arom, J PC $=5.0 \mathrm{~Hz}), 137.8(\mathrm{CH}$ arom), 136.7 (CH arom), 134.6 (C arom), 134.3 (C arom), 132.5 (C arom), 132.4 (C arom), 131.3 (C arom), 130.8 (C arom), 128.7 (CH arom), 128.5 (CH arom), 126.9 ( $\mathrm{CH}$ arom), 126.7 (CH arom), 126.6 (CH arom), 126.4 (CH arom), 124.8 (CH arom), 124.7 (CH arom), 123.5 (t, C arom, J PC $=5.5 \mathrm{~Hz}), 122.6(\mathrm{t}, \mathrm{C}$ arom, J PC $=3.0 \mathrm{~Hz}), 69.5(\mathrm{CH})$, $\left.47.3\left(\mathrm{CH}_{2}\right), 22.2\left(\mathrm{CH}_{3}\right), 0.2\left(\mathrm{Si}\left(\mathrm{CH}_{3}\right)_{3}\right), 0.1\left(\mathrm{SiCH}_{3}\right)_{3}\right)$. ${ }^{1} \mathrm{H} \mathrm{NMR}$ (benzene- $\mathrm{d}_{6}$ ): $\delta 8.08(\mathrm{~s}, 2 \mathrm{H}$, arom), $8.07(\mathrm{~s}, 2 \mathrm{H}$, arom), $7.69(\mathrm{~d}$, $2 \mathrm{H}$, arom, 3j $=7.6 \mathrm{~Hz}), 7.66(\mathrm{~d}, 2 \mathrm{H}$, arom, 3j $=7.6 \mathrm{~Hz}), 7.31$ $\left(\mathrm{d}, 2 \mathrm{H}\right.$, arom, 3 $\left.{ }^{\mathrm{J}}=8.5 \mathrm{~Hz}\right), 7.25\left(\mathrm{~d}, 2 \mathrm{H}\right.$, arom, 3 $\left.{ }^{3}=8.5 \mathrm{~Hz}\right)$, $7.12(\mathrm{dd}, 2 \mathrm{H}$, arom, J $=7.6 \mathrm{~Hz}, \mathrm{~J}=7.3 \mathrm{~Hz}), 7.10(\mathrm{dd}, 2 \mathrm{H}$, arom, J $=7.4 \mathrm{~Hz}$, J $=7.5 \mathrm{~Hz}), 6.87(\mathrm{dd}, 2 \mathrm{H}$, arom, J $=7.6 \mathrm{~Hz}$, $\mathrm{J}=7.7 \mathrm{~Hz}), 6.85(\mathrm{dd}, 2 \mathrm{H}$, arom, $\mathrm{J}=7.7 \mathrm{~Hz}, \mathrm{~J}=7.4 \mathrm{~Hz}), 4.48$ $(\mathrm{m}, 2 \mathrm{H}, \mathrm{CH}), 1.90\left(\mathrm{t}, 2 \mathrm{H}, \mathrm{CH}_{2}, 3 \mathrm{~J}=6.1 \mathrm{~Hz}\right), 0.69\left(\mathrm{~d}, 6 \mathrm{H}, \mathrm{CH}_{3}\right.$, 3) $=6.5 \mathrm{~Hz}), 0.50\left(\mathrm{~s}, 36 \mathrm{H}, \mathrm{Si}\left(\mathrm{CH}_{3}\right)_{3}\right)$.

Compound 6. This compound was prepared as described for 3a. (2S,4S)-Pentane-2,4-diol has been used for the synthesis of $\mathbf{6}$. The product was purified by column chromatography $\left(1 \% \mathrm{Et}_{3} \mathrm{~N} / 5 \% \mathrm{EtOAC} / \mathrm{PE} 60-80{ }^{\circ} \mathrm{C},(\mathrm{v} / \mathrm{v}), \mathrm{R}_{\mathrm{f}}=0.27\right)$. Yield: $73 \%(0.51 \mathrm{mmol}, 0.53 \mathrm{~g})$ of a white solid. Mp: $140-142$ ${ }^{\circ} \mathrm{C}$. Anal. Calcd for $\mathrm{C}_{57} \mathrm{H}_{66} \mathrm{O}_{6} \mathrm{P}_{2} \mathrm{Si}_{4}$ : C, 67.02; $\mathrm{H}, 6.52$. Found: C, 67.24; $\mathrm{H}, 6.81$. $[\alpha]^{20}{ }_{\mathrm{D}}=64.7^{\circ}\left(\mathrm{c}=0.10, \mathrm{CH}_{2} \mathrm{Cl}_{2}\right.$ ). ${ }^{31} \mathrm{P}-{ }^{1} \mathrm{H}$ NMR (benzene- $\left.\mathrm{d}_{6}\right): \delta 144.6\left(\mathrm{~d},{ }^{3} \mathrm{~J} \mathrm{PH}=8.5 \mathrm{~Hz}\right) .{ }^{13} \mathrm{C}$ NMR (benzene- $\mathrm{d}_{6}$ ): $\delta 152.4\left(\mathrm{~d}, \mathrm{C}\right.$ arom, ${ }^{3} \mathrm{~J} \mathrm{PC}=3.0 \mathrm{~Hz}$ ), 152.4 (d, C arom, 3) PC $=1.5 \mathrm{~Hz}), 137.3(\mathrm{CH}$ arom), $136.9(\mathrm{CH}$ arom), 134.5 (C arom), 134.3 (C arom), 132.5 (C arom), 132.3 (C arom), 131.3 (C arom), 130.0 (C arom), 128.5 (CH arom), $128.3(\mathrm{CH}$ arom), 126.9 (CH arom), 126.7 ( $\mathrm{CH}$ arom), 124.8 ( $\mathrm{CH}$ arom),
124.7 ( $\mathrm{CH}$ arom), 123.3 (CH arom), 123.2 (CH arom), 122.7 (C arom, $), 122.6(\mathrm{C}$ arom $), 70.5(\mathrm{CH}), 45.4\left(\mathrm{CH}_{2}\right), 21.8\left(\mathrm{CH}_{3}\right), 21.7$ $\left.\left.\left(\mathrm{CH}_{3}\right), 0.3\left(2 \mathrm{Si}\left(\mathrm{CH}_{3}\right)_{3}\right), 0.0\left(\mathrm{SiCH}_{3}\right)_{3}\right),-0.1\left(\mathrm{SiCH}_{3}\right)_{3}\right) .{ }^{1} \mathrm{H} \mathrm{NMR}$ (benzene- $\left.\mathrm{d}_{6}\right): \delta 8.14(\mathrm{~s}, 2 \mathrm{H}$, arom), $8.05(\mathrm{~s}, 2 \mathrm{H}$, arom), $7.71(\mathrm{~d}$, $2 \mathrm{H}$, arom, 3j $=8.2 \mathrm{~Hz}), 7.66(\mathrm{~d}, 2 \mathrm{H}$, arom, 3j $=8.2 \mathrm{~Hz}), 7.30$ $\left(\mathrm{d}, 2 \mathrm{H}\right.$, arom, $\left.{ }^{3} \mathrm{j}=8.5 \mathrm{~Hz}\right), 7.22\left(\mathrm{~d}, 2 \mathrm{H}\right.$, arom, $\left.{ }^{3} \mathrm{~s}=8.5 \mathrm{~Hz}\right)$, 7.13 (dd, $2 \mathrm{H}$, arom, J $=7.6 \mathrm{~Hz}$, J $=9.0 \mathrm{~Hz}$ ), 7.10 (dd, $2 \mathrm{H}$, arom, J $=9.0 \mathrm{~Hz}, \mathrm{~J}=8.3 \mathrm{~Hz}), 6.86(\mathrm{dd}, 2 \mathrm{H}$, arom, J $=7.9 \mathrm{~Hz}$, $\mathrm{J}=7.7 \mathrm{~Hz}), 6.83(\mathrm{dd}, 2 \mathrm{H}$, arom, $\mathrm{J}=7.7 \mathrm{~Hz}, \mathrm{~J}=7.4 \mathrm{~Hz}), 4.02$ $(\mathrm{m}, 2 \mathrm{H}, \mathrm{CH}), 1.72\left(\mathrm{t}, 2 \mathrm{H}, \mathrm{CH}_{2},{ }^{3} \mathrm{~J}=7.0 \mathrm{~Hz}\right), 0.69\left(\mathrm{~d}, 6 \mathrm{H}, \mathrm{CH}_{3}\right.$, 3) $=6.1 \mathrm{~Hz}), 0.51\left(\mathrm{~s}, 18 \mathrm{H}, \mathrm{Si}\left(\mathrm{CH}_{3}\right)_{3}\right), 0.44\left(\mathrm{~s}, 18 \mathrm{H}, \mathrm{Si}\left(\mathrm{CH}_{3}\right)_{3}\right)$.

Compound 7. This compound was prepared as described for 3a. (2R 4R)-Pentane-2,4-diol and (R)-(+)-3,3'-bis(trimethylsilyl)-2,2'-bisnaphthol have been used as starting compounds. Enantiomers 6 and $\mathbf{7}$ show similar NMR spectroscopic data. Yield: $70 \%(0.49 \mathrm{mmol}, 0.51 \mathrm{~g})$ of a white solid. Mp: $141-143$ ${ }^{\circ} \mathrm{C}$. Anal. Calcd for $\mathrm{C}_{57} \mathrm{H}_{66} \mathrm{O}_{6} \mathrm{P}_{2} \mathrm{Si}_{4}: \mathrm{C}, 67.02 ; \mathrm{H}, 6.52$. Found: $\mathrm{C}, 67.17 ; \mathrm{H}, 6.61$. $[\alpha]^{20}{ }_{\mathrm{D}}=-63.8^{\circ}\left(\mathrm{c}=0.10, \mathrm{CH}_{2} \mathrm{Cl}_{2}\right)$.

Compound 8. Compound (R)-2a (1.63 mmol, $0.70 \mathrm{~g})$ was azeotropically dried with toluene $(3 \times 1 \mathrm{~mL})$, dissolved in toluene $(10 \mathrm{~mL})$, and added slowly to a solution of $\mathrm{PCl}_{3}(1.80$ $\mathrm{mmol}, 157 \mu \mathrm{L})$ and $\mathrm{Et}_{3} \mathrm{~N}(7.5 \mathrm{mmol}, 0.78 \mathrm{~mL})$ in toluene (10 $\mathrm{mL}$ ) at $0{ }^{\circ} \mathrm{C}$. Subsequently the reaction mixture was stirred for $4 \mathrm{~h}$ at $50{ }^{\circ} \mathrm{C}$. The formed amine salts were removed by filtration. Evaporation to dryness gave the crude phosphorochloridite ( $\left.{ }^{31} \mathrm{P} \mathrm{NMR}\left(\mathrm{CDCl}_{3}\right): \delta 177\right)$ which was used without further purification and was dissolved in toluene $(10 \mathrm{~mL})$ and $\mathrm{Et}_{3} \mathrm{~N}(5.0 \mathrm{mmol}, 0.52 \mathrm{~mL})$. To this solution was added $(2 \mathrm{R}, 4 \mathrm{R})$ pentane-2,4-diol ( $1.63 \mathrm{mmol}, 0.17 \mathrm{~g}$, azeotropically dried with $3 \times 1 \mathrm{~mL}$ toluene) in toluene $(10 \mathrm{~mL})$ at $-55^{\circ} \mathrm{C}$. The reaction mixture was stirred overnight at room temperature, filtrated, and evaporated to dryness. The monophosphite $(R, 2 R, 4 R)$ was purified by column chromatography (10\% EtOAc/PE $60-80^{\circ} \mathrm{C}$ $\left.(\mathrm{v} / \mathrm{v}), \mathrm{R}_{\mathrm{f}}=0.48\right)$. Yield: $61 \%(1.00 \mathrm{mmol}, 0.56 \mathrm{~g})$ of a white solid. ${ }^{31} \mathrm{P}$ NMR (benzene- $\mathrm{d}_{6}$ ): $\delta 150.12(\mathrm{~s})$. The product was dissolved in toluene $(10 \mathrm{~mL})$ and $\mathrm{Et}_{3} \mathrm{~N}(5.0 \mathrm{mmol})$. To this solution was added an in situ prepared solution of (S)-(-)-3,3'bis(trimethylsilyl)-2,2'-bisnaphthol phosphorochloridite (1.00 $\mathrm{mmol}$ ) at room temperature. The reaction mixture was stirred overnight, filtrated, and evaporated to dryness. The product was purified by column chromatography $\left(15 \% \mathrm{EtOAc} / 2 \% \mathrm{Et}_{3} \mathrm{~N} /\right.$ PE $\left.60-80{ }^{\circ} \mathrm{C}(\mathrm{v} / \mathrm{v} / \mathrm{v}), \mathrm{R}_{\mathrm{f}}=0.79\right)$. Yield: $84 \%$ (0.84 mmol, 0.87 g) of a white solid. Mp: $122-124^{\circ} \mathrm{C}$. Anal. Calcd for $\mathrm{C}_{57} \mathrm{H}_{66^{-}}$ $\mathrm{O}_{6} \mathrm{P}_{2} \mathrm{Si}_{4}: \mathrm{C}, 67.02 ; \mathrm{H}, 6.52$. Found: $\mathrm{C}, 67.20 ; \mathrm{H}, 6.54$. $[\alpha]^{20} \mathrm{D}$ $=0.00^{\circ}\left(\mathrm{c}=0.10, \mathrm{CH}_{2} \mathrm{Cl}_{2}\right.$ ). ${ }^{31} \mathrm{P} \mathrm{NMR}$ (benzene- $\left.\mathrm{d}_{6}\right): \delta 144.4$ (s) and $144.2(\mathrm{~s}) .{ }^{1} \mathrm{H} N M R$ (benzene- $\left.\mathrm{d}_{6}\right): \delta 8.06(\mathrm{~m}, 4 \mathrm{H}$, arom), 7.65 (m, 4H, arom), 7.30 (m, 4H, arom), 7.10 (m, 4H, arom), $6.83(\mathrm{~m}, 4 \mathrm{H}, \mathrm{arom}), 4.16(\mathrm{~m}, 1 \mathrm{H}, \mathrm{CH}), 3.96(\mathrm{~m}, 1 \mathrm{H}, \mathrm{CH}), 2.06$ $\left(\mathrm{m}, 1 \mathrm{H}, \mathrm{CH}_{2}\right), 1.77\left(\mathrm{~m}, 1 \mathrm{H}, \mathrm{CH}_{2}\right), 0.99\left(\mathrm{~d}, 3 \mathrm{H}, \mathrm{CH}_{3}, 3 \mathrm{~J}=2.5\right.$ $\mathrm{Hz}), 0.85\left(\mathrm{~d}, 3 \mathrm{H}, \mathrm{CH}_{3}, 3 \mathrm{~J}=2.6 \mathrm{~Hz}\right), 0.52\left(\mathrm{~s}, 9 \mathrm{H}, \mathrm{Si}\left(\mathrm{CH}_{3}\right)_{3}\right)$, $0.49\left(\mathrm{~s}, 9 \mathrm{H}, \mathrm{Si}\left(\mathrm{CH}_{3}\right)_{3}\right), 0.46\left(\mathrm{~s}, 9 \mathrm{H}, \mathrm{Si}\left(\mathrm{CH}_{3}\right)_{3}\right), 0.43(\mathrm{~s}, 9 \mathrm{H}$, $\left.\mathrm{Si}\left(\mathrm{CH}_{3}\right)_{3}\right)$.

Acknowledgment. We are grateful to the IOPKatalyse (Innovation Oriented Research Programme on Catalysis) for financial support. We are indebted to Dr. C. J. Schaverien and A. J. van der Linden, Shell Research and Technology Center, Amsterdam, for a gift of diol (R/S)-2d.

OM970172D 